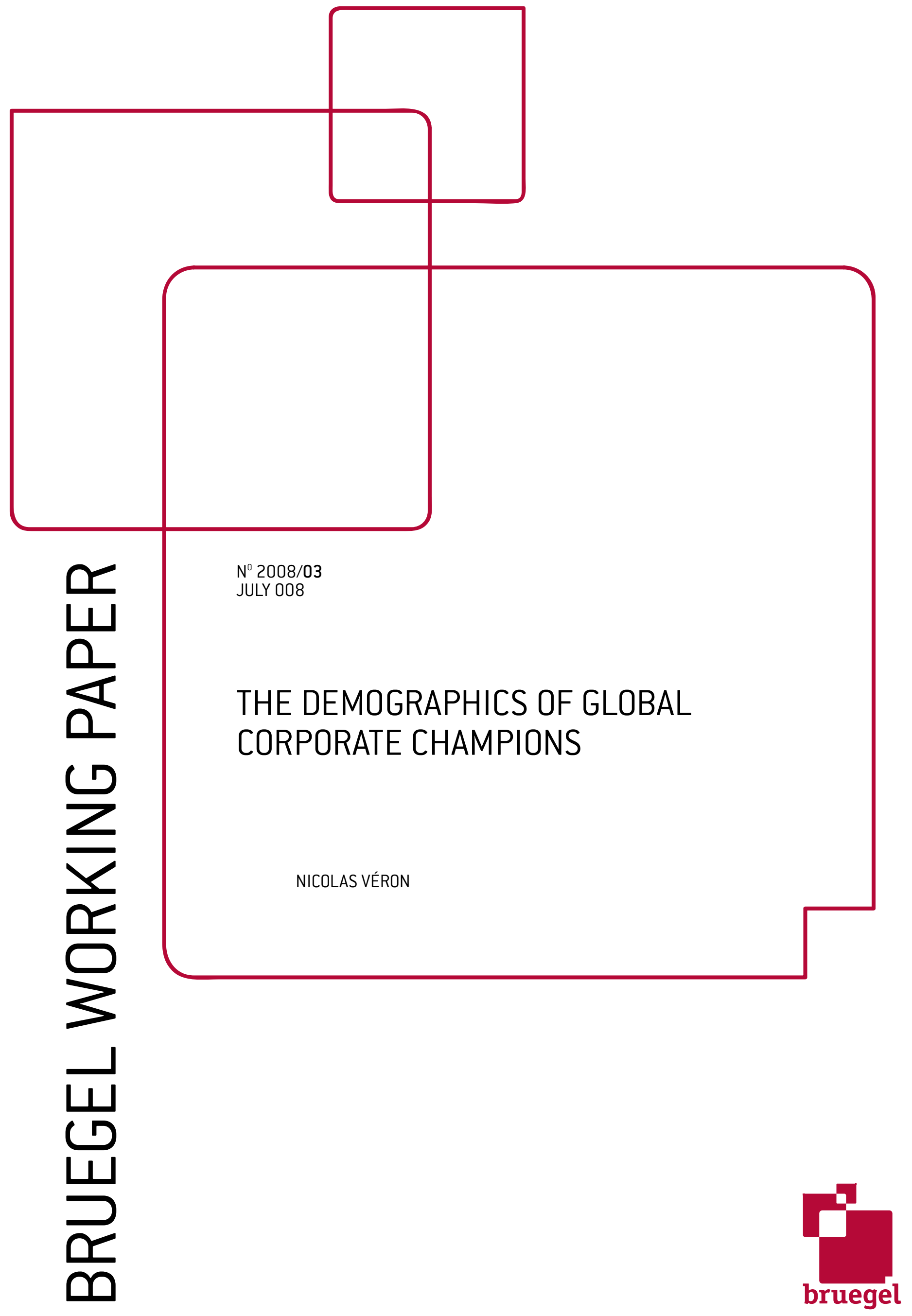


Bruegel Working Paper

\title{
The Demographics of Global Corporate Champions
}

\author{
Nicolas Véron
}

July 2008

\section{Layman's summary}

This Working Paper presents a novel dataset documenting the demographics of the world's 500 largest companies by market capitalisation, as of 30 September 2007. Assigning a birth date to a large company is not a straightforward exercise and involves a measure of judgment, which possibly explains why data on corporate demographics have not been more widely researched in spite of their potential interest to policymakers. However, our methodology, based on the collection of narrative data which is publicly accessible online, generates robust results, which we hope may help spur increased interest in corporate demographics.

Corporate demographics provide a basis for comparing different national and regional business environments. Our focus on the very largest companies illustrates a stark contrast between the main global economic regions. In Europe and Japan, large companies tend to be fairly old, and very few 'global champions' have been created in the past half-century. In the United States, older champions coexist with a significant number of new ones, generated mainly in high-tech sectors and low/mid-tech services. In emerging economies, most champions were born in the second half of the $20^{\text {th }}$ century and reflect a rapid catch-up growth process. Policy implications, especially for Europe and Japan, are very briefly discussed in the conclusion, with an emphasis on enabling the emergence of innovation ecosystems and on unleashing the growth potential of services sectors as possible ways for Europe and Japan to regain some of their ability to generate new global corporate champions. 
Corporate strategy and operations are often characterised by their focus on a short-term horizon, such as the next quarterly earnings or, at the very longest, a three-year or five-year business plan. In addition, an ever-growing volume of mergers and acquisitions activity over the past few decades has resulted in constant shifts in the boundaries of companies, especially the larger ones.

However, in spite of the short term-oriented features of corporate life, most companies simultaneously display a strong sense of continuity over time. This is true in the way they present themselves to their internal and external stakeholders, including in many cases through explicit references to the company's 'founding fathers' and the inspiration that can still be derived from their early experience. Through the analysis of detailed case studies, Berger (2005) illustrates that the behaviour and strategy of companies large and small are strongly affected, and to some extent determined, by their historical experience and legacy, an idiosyncratic determinant that can in some cases be at least as powerful as other features such as a company's sector or nation of origin.

Corporate demographics appear not to have been widely researched by economists, perhaps because the history of most large companies is so intricate and marked by numerous acquisitions, mergers, and divestments. Those studies that exist generally cover the US and concentrate on the earlier stages of a company's life, which all else being equal display a more linear path of development in that they focus on the time period between creation and initial public offering (IPO). Typically, the Field-Ritter dataset of company founding dates, used in Field and Karpoff (2002) and Loughran and Ritter (2004), based on data from the Center for Research in Security Prices (CRSP) at the University of Chicago Graduate School of Business, includes 8,464 firms which went public in the US after 1975, and does not include any information that predates the $20^{\text {th }}$ century. Jovanovic and Rousseau (2001) also use the CRSP database and have extended it back from 1925 to 1885 using newspaper sources, thus creating a combined database of 21,516 US companies which they trace from founding to IPO ${ }^{1}$.

In this working paper we consider the world's largest companies, irrespective of their age or geographical origin. For each of them we identify a date and place of creation and correlate the birth date with corporate characteristics such as industry and location of headquarters. The dataset of 500 companies can be used as a way to compare structural features of different national and regional business environments.

\section{Sample used: the world's top 500}

The sample used in this research is the ranking of the world's 500 largest companies by market capitalisation at market exchange rates, which has been compiled by the Financial Times on a yearly basis since 1998 and on a quarterly basis since 2003 (FT Global 500). It is based on a collection of national rankings and comparison at market exchange rates, resulting in a global ranking by market capitalisation measured in current US dollars. The corresponding methodology, which excludes some companies which are publicly listed but with a tiny free float, is detailed at http://www.ft.com/reports/ft500.

Specifically, the demographic analysis carried out in this working paper is based on the companies in the FT Global 500 ranking at 30 September 2007, the latest available at the time

\footnotetext{
${ }^{1}$ I am grateful to Narcissa Balta for her efficient research assistance in identifying these references.
} 
of our research. The market value threshold to be included in the ranking was approximately US\$20bn: the $500^{\text {th }}$-ranked company, DnB Nor, was worth $\$ 20,390 \mathrm{~m}$ on 30 September 2007. We often use the word 'champion' or 'global champion' in the rest of this text to refer to the 500 companies included in the ranking.

For each champion, we assign a sector (industry), and a country and region.

- The 'sector' is assigned with reference to a list of the following nine categories: Business Services; Consumer Products and Services; Energy Services and Utilities; Banking and Finance; Health and Life Sciences; Insurance; Manufacturing; Oil, Gas and Mining; Telecoms and Media. The reason we have devised this list rather than take a standard sector classification is that there is no such classification of sectors which has gained wide enough acceptance to be considered the obvious reference for ranking listed companies. For example, the United Nations' ISIC classification of 16 sectors include some of little or no relevance to a ranking of listed companies (such as fishing, public administration and defence, education, health and social work, activities of private households as employers, extraterritorial organisations and bodies); by contrast some other ISIC sectors are very broad and it is necessary to divide them into subsectors (such as 'manufacturing', which includes both consumer goods and other manufacturing activities, or 'financial intermediation' which includes both banking and insurance). The list we use corresponds to widely accepted practice in financial market research.

In the case of conglomerates or diversified companies which combine activities in several sectors, the sector assigned is the one which has the largest share of the company's revenue. Given the breadth of the sector classification we use, this is a robust method and except in extremely few cases there is no ambiguity in sector allocation.

- The 'country' is defined as the one where the operational headquarters of the company is located. The 'region' corresponds to one of four worldwide country groupings: the United States; Europe (which includes the EU, Norway, and Switzerland); Australia, Canada and Japan (grouped together as the three non-European, non-US industrialised economies); and 'emerging', which includes all other countries. This definition is unambiguous at the regional level and generally unambiguous as well at the country level ${ }^{2}$.

The sectoral composition of the FT Global 500 ranking varies somewhat over time, which means that each ranking has temporary features linked to cycles in the economy, technology, exchange rates, or stock market dynamics. To give a sense of how the ranking we use compares to previous cycles, Table 1 displays this variation by analysing four successive rankings over the past ten years ${ }^{3}$. From that perspective, the ranking used in this working paper, September 2007, is one in which the banking sector appears strongly represented (banking valuations were already off their peak at that date but have declined further over

\footnotetext{
${ }^{2}$ In three cases, namely EADS, Reed Elsevier and Unilever, the company has two parallel headquarters in two different countries. The ambiguity, though, does not extend to the region, which is Europe in all three cases. The three other cases recorded in the FT Global 500 as ambiguous are BHP Billiton, Carnival Cruises and Rio Tinto, which we respectively categorise as Australian, American, and British, based on the location of operational decision-making as opposed to legal structure.

${ }^{3}$ We show the weight of each sector as a proportion of the aggregate market capitalisation of all companies in the sample. We identify six occurrences of double counts when using this method, when one company in the sample holds a significant equity stake in another: NTT in NTT DoCoMo; Itausa in Banco Itau; Yahoo! in Yahoo! Japan; Wal-Mart in Walmex; Bank of China in BoC Hong Kong; and InBev in Ambev. These double counts have only a minor impact on the calculation of aggregate market value and have therefore been disregarded. Reliance Industries and Reliance Communications are separate companies, both parts of the Reliance group. The cross-shareholdings among companies from former Japanese zaibatsu (Mitsubishi, Mitsui, Sumitomo) may result in additional double counts but the impact has not been considered material.
} 
subsequent months), as well as the Oil, Gas and Mining sector in the wake of a sharp increase in commodity prices.

Table 1

Evolution of the sectoral composition of the FT Global 500 ranking, 1998-2007

(share of aggregate market capitalisation of all companies in the ranking)

\begin{tabular}{|l|c|c|c|c|}
\hline & September 1998 & January 2001 & June 2004 & September 2007 \\
\hline Banking and Finance & $15 \%$ & $16 \%$ & $18 \%$ & $21 \%$ \\
\hline Business Services & $5 \%$ & $6 \%$ & $6 \%$ & $4 \%$ \\
\hline Consumer Products and Services & $14 \%$ & $11 \%$ & $14 \%$ & $11 \%$ \\
\hline Energy Services and Utilities & $5 \%$ & $3 \%$ & $3 \%$ & $5 \%$ \\
\hline Health and Life Sciences & $12 \%$ & $11 \%$ & $12 \%$ & $8 \%$ \\
\hline Insurance & $7 \%$ & $6 \%$ & $6 \%$ & $6 \%$ \\
\hline Manufacturing & $21 \%$ & $25 \%$ & $20 \%$ & $20 \%$ \\
\hline Oil, Gas and Mining & $7 \%$ & $6 \%$ & $10 \%$ & $15 \%$ \\
\hline Telecoms and Media & $14 \%$ & $17 \%$ & $12 \%$ & $10 \%$ \\
\hline Total \% & $100 \%$ & $100 \%$ & $100 \%$ & $100 \%$ \\
\hline Total Market Cap (\$trn) & 12.7 & 19.4 & 17.4 & 29.5 \\
\hline
\end{tabular}

The regional composition of the ranking also changes over time, as is documented by Table 2 . The main development here is the dramatic rise of emerging economies, especially after a series of high-profile initial public offerings in China since the mid-2000s. This has been mirrored in a striking decline of the relative share of the United States, which is attributable partly but not entirely to exchange-rate movements ${ }^{4}$.

Table 2

Evolution of the regional composition of the FT Global 500 ranking, 1998-2007

(share of aggregate market capitalization of all companies in the ranking)

\begin{tabular}{|l|c|c|c|c|}
\hline & September 1998 & January 2001 & June 2004 & September 2007 \\
\hline Europe & $32 \%$ & $30 \%$ & $29 \%$ & $32 \%$ \\
\hline United States & $57 \%$ & $56 \%$ & $53 \%$ & $38 \%$ \\
\hline Australia, Canada and Japan & $9 \%$ & $12 \%$ & $12 \%$ & $12 \%$ \\
\hline Emerging Countries & $2 \%$ & $3 \%$ & $5 \%$ & $18 \%$ \\
\hline Total \% & $100 \%$ & $100 \%$ & $100 \%$ & $100 \%$ \\
\hline Total Market Cap \$trn & 12.7 & 19.4 & 17.4 & 29.5 \\
\hline
\end{tabular}

\footnotetext{
${ }^{4}$ Most of the declined occurred in 2004-2006, a period of relative exchange rate stability.
} 
One result of this trend is that the FT Global 500 September 2007 ranking is an unprecedentedly balanced one, with European companies, US companies, and companies from the rest of the world forming groups of similar sizes of 156, 178, and 166 companies respectively.

Different regions also display different sectoral profiles, reflecting their various levels of development and industry specialisations. Table 3 illustrates this diversity. Europe provides a balanced profile except for its highly concentrated and publicly-listed electricity sector; the US is strong in life sciences and manufacturing (which includes electronic hardware); Japan is concentrated on manufacturing and to a lesser extent on consumer products and services; in the rest of the world, financial services and commodities represent the bulk of total market value.

Table 3

Sectoral composition of regional subsamples of the FT Global 500 ranking at 30 Sept 07

(sectoral shares of the aggregate market capitalisation of each region)

\begin{tabular}{|l|c|c|c|c|c|c|}
\hline & Europe & US & Rest of World $\rightarrow$ & Japan & AU+CA & Emerging \\
\hline Banking and Finance & $22 \%$ & $15 \%$ & $29 \%$ & $17 \%$ & $\mathbf{3 3 \%}$ & $\mathbf{3 2 \%}$ \\
\hline Business Services & $2 \%$ & $7 \%$ & $3 \%$ & $6 \%$ & $2 \%$ & $2 \%$ \\
\hline $\begin{array}{l}\text { Consumer Products } \\
\text { and Services }\end{array}$ & $13 \%$ & $15 \%$ & $5 \%$ & $\mathbf{1 7 \%}$ & $2 \%$ & $2 \%$ \\
\hline $\begin{array}{l}\text { Energy Services and } \\
\text { Utilities }\end{array}$ & $\mathbf{1 0 \%}$ & $2 \%$ & $3 \%$ & $3 \%$ & $0 \%$ & $3 \%$ \\
\hline $\begin{array}{l}\text { Health and Life } \\
\text { Sciences }\end{array}$ & $8 \%$ & $\mathbf{1 2 \%}$ & $2 \%$ & $6 \%$ & $0 \%$ & $1 \%$ \\
\hline Insurance & $6 \%$ & $6 \%$ & $6 \%$ & $2 \%$ & $\mathbf{1 1 \%}$ & $7 \%$ \\
\hline Manufacturing & $17 \%$ & $\mathbf{2 4 \%}$ & $19 \%$ & $\mathbf{3 8 \%}$ & $9 \%$ & $15 \%$ \\
\hline Oil, Gas and Mining & $14 \%$ & $10 \%$ & $21 \%$ & $1 \%$ & $\mathbf{3 4 \%}$ & $\mathbf{2 5 \%}$ \\
\hline Telecoms and Media & $9 \%$ & $9 \%$ & $12 \%$ & $10 \%$ & $8 \%$ & $\mathbf{1 4 \%}$ \\
\hline Total \% & $100 \%$ & $100 \%$ & $100 \%$ & $100 \%$ & $100 \%$ & $100 \%$ \\
\hline \# companies & 156 & 178 & 166 & 44 & 36 & 86 \\
\hline
\end{tabular}

\section{Assigning birth dates: methodological choices}

Our 'demographic' analysis is based on the collection, for each company in the ranking, of narrative historical data from publicly accessible sources on the internet. These sources are company websites, which often include a section on the company's history, the Wikipedia online encyclopedia and, in a limited number of cases when insufficient information was available from the previously mentioned sources, other publicly accessible sources such as press articles. These companies are all large and have typically had high visibility and, in many cases, a significant impact on the societies in which they originated. For this reason, their history is generally well and publicly documented. 
Our dataset is presented as an Appendix. It is also available online in Google Spreadsheet format at http://spreadsheets.google.com/pub?key=pDNVZRRJsKO4qJaOogboxbg. For each company, it provides three items linked to its creation:

- the date of creation of the ancestor company or, in cases where no such company could be identified (see below), the estimated date of launch of the ancestor activities ('birth date');

- the name of the ancestor company or indication of ancestor activities ('name at creation');

- the city, and state (for US companies) or country (for others), where the ancestor company (or ancestor activities) was created ('place of creation').

Assigning a birth date to a large company can be either a straightforward or somewhat convoluted process, depending on the case. The date of incorporation of the legal entity which currently forms the parent company is often irrelevant, given the intricate pattern of restructurings, mergers, acquisitions, spin-offs, and in some cases nationalisations and/or privatisations which have shaped most of today's corporate champions. Thus, a qualitative analysis of each company's history is necessary to assemble meaningful information. The sample can be decomposed as follows, in decreasing order of straightforwardness.

- 306 global champions present a fairly linear history from creation to current form. In such cases, the birth date has been determined as the date of creation of the initial company or business.

For example, Sumitomo traces its origins to the creation of the Sumitomo store in 1640 in Tokyo; Procter \& Gamble was born when candlemaker William Procter and soapmaker James Gamble became business partners in 1837 in Cincinnati.

For 224 of these, the name of the company has stayed essentially unchanged since creation, while for 79 there has been a change of name in the course of the company's history, often by renaming the company after a successful brand, or as a consequence of major restructuring or acquisition.

An estimated 28 of these 306 companies were created by national state authorities, the rest were essentially private sector initiatives.

- 95 global champions result from one or several mergers among entities of comparable size. In such cases, the birth date has been determined as the date of creation of the oldest merged entity.

For example, Intesa Sanpaolo results from the 2006 merger between Banca Intesa and Sanpaolo IMI, which itself has its roots, including through the 1998 merger between Istituto Bancario San Paolo di Torino and Istituto Mobiliare Italiano, in the establishment of the Compagnia di San Paolo in 1563 in Turin.

In 41 of these cases, the current name includes a reference to the name of the initial company, while in the other 54 the name has changed, most often as a consequence of the merger(s).

An estimated 5 of the 95 initial companies were created by national state authorities, the rest were essentially private sector initiatives.

- 36 global champions trace their origins directly to the establishment of a new business (with or without separate legal personality) within an existing corporate entity, which was later partly or entirely spun off, or as a joint venture by several existing entities. In such cases, the birth date has been determined as the date of creation of the new business or joint venture. 
For example, Swiss Re was established in 1863 as a reinsurance joint venture between three existing Swiss insurers; Alcan is the successor of the Canadian subsidiary set up in 1902 by the Pittsburgh Aluminum Company (now Alcoa) of 1894, and spun off as an independent company in 1928, so 1902 was taken as Alcan's birth date.

These include, among others, foreign subsidiaries or joint ventures which have been listed as separate entities (such as Alcan, Bank of China Hong Kong, Yahoo! Japan, Wal-Mart de Mexico), as well as different entities of the pre-1945 Japanese zaibatsu (such as Mitsubishi Electric or Sumitomo Metal Industries).

All these companies except one originated in the private sector.

- 28 global champions have an activity which mainly or significantly comes from a company older than the parent, which was purchased at some stage of the parent's history. In such cases, the birth date has been determined as the date of creation of the older, acquired company.

For example, Suez traces its origins to the Universal Suez Ship Canal Company created in 1858 in Paris to build the Suez Canal, but a major part of its assets as of September 2007, including control of most of Belgium's electricity generation, come from the purchase in 1988 of Société Générale de Belgique, which succeeded the 1822 Algemeene Nederlandsche Maatschappij ter Begunstiging van de Volksvlijt after Belgium became independent in 1830. Thus, the birth date adopted for Suez is 1822.

Apart from Suez, all other 27 companies in this category originate in the private sector.

- 35 global champions have been created by consolidating a number of pre-existing assets, in most cases in the context of major restructuring of entire industries. In such cases, the birth date could not be documented precisely but has been estimated as the date of start of the activities which were consolidated into the newly formed entity ${ }^{5}$.

For example, National Grid traces its roots to the UK Central Electricity Generating Board, which was created in 1957 and took over existing electricity transmission assets, some of which dated back to the start of electricity generation in the United Kingdom in the late $19^{\text {th }}$ century. In this case, 1880 was taken as the estimated birth date for the oldest corresponding assets and thus for National Grid.

In such cases where no single company or entity could be identified as an ancestor, the item 'name at creation' in the dataset is a summary description of ancestor activities and appears in square brackets.

An estimated 29 companies in this category were created by national governments as state entities, and later partly or completely privatised.

Thus, the total sample of 500 companies is composed as follows:

\footnotetext{
${ }^{5}$ This method tends to underestimate the corresponding companies' age, as developments in their present sector may have been undertaken by an older, pre-existing company. To illustrate this bias, Dominion Resources, a Virginia-based power and energy utility, traces it roots to the Upper Appomattox Company, created in 1795 to promote navigation on the Appomattox River. Lacking this information, under the method presented in this category we would have assigned it a birth date corresponding to the birth of the electricity generation sector, in the last quarter of the $19^{\text {th }}$ century. Given the number and profile of companies in this category, however, we consider that this bias does not result in material distortion of our research results.
} 
Table 4

Determination of birth dates for the $\mathbf{5 0 0}$ companies in the sample

\begin{tabular}{|l|l|l|}
\hline No. of companies & $\%$ of total & Determination of birth date \\
\hline 306 & $61 \%$ & Creation of the present company or of its direct 'ancestor' entity \\
\hline 95 & $19 \%$ & $\begin{array}{l}\text { Creation of the [ancestor of the] oldest of several merger components } \\
\text { which formed the present company }\end{array}$ \\
\hline 36 & $7 \%$ & $\begin{array}{l}\text { Creation of the [ancestor of the] present company as a new business or } \\
\text { joint venture by pre-existing corporate entities }\end{array}$ \\
\hline 35 & $6 \%$ & $\begin{array}{l}\text { Creation of the oldest significant component which the [ancestor of } \\
\text { the] present company later acquired }\end{array}$ \\
\hline 500 & $7 \%$ & $\begin{array}{l}\text { Estimate of the creation of the oldest among assets later consolidated } \\
\text { into the [ancestor of the] present company }\end{array}$ \\
\hline
\end{tabular}

In a limited number of cases, two or more champions are linked by a shared history, which makes the determination of the birth date more a matter of judgment. We provide here a complete list of these particularly intricate cases.

- Novartis and Syngenta: Syngenta, formerly the agricultural chemicals division of Novartis (itself the result of the 1996 merger of Ciba-Geigy and Sandoz), was spun off in 2000 as an independent company. We retained 1756 (creation of the Geigy pharmacy in Basel) as birth date for Novartis, and 1939 (creation of the agricultural chemicals division at Sandoz) as birth date for Syngenta.

- BG and Centrica: British Gas was formed in 1974 by the consolidation of twelve regional Gas Boards formed in 1948 following the nationalisation of the UK gas industry, of which the earliest component we identified was the London Gas Light and Coke Company, created 1812. The natural gas fields of the North Sea were exploited from 1967 on. In 1997, British Gas (which had been privatised in 1986) was split into two entities, Centrica (which inherited the UK gas distribution networks) and BG (which inherited the international exploration and production business). We took 1812 as the birth date for Centrica, and 1967 for BG.

- Alcatel-Lucent and Alstom: both companies were born from Alcatel-Alsthom, formerly Compagnie Générale d’Electricité (CGE, created 1898). The businesses that currently form Alstom, which was spun off in 1998, trace their roots to the 1928 tripartite merger of assets from Société Alsacienne de Constructions Mécaniques (itself rooted in Atelier de Construction Koechlin, created 1839), Compagnie Française Thomson-Houston (created 1893) and CGE itself, to form Alsthom which was later merged into CGE. We adopted 1898 (CGE's creation) as birth date for Alcatel-Lucent, and 1839 (Alsthom's roots) as birth date for Alstom.

- Veolia Environment and Vivendi: Compagnie Générale des Eaux, created in 1853, evolved in the late 1990s and early 2000s into a media conglomerate and renamed itself Vivendi in 1998. In 2000 Vivendi spun off most of the former Compagnie's assets as a separate listed entity, which in 2003 renamed itself Veolia Environnement. For the latter we took 1853 as the birth date; for Vivendi we took the date of creation of the oldest of its present assets, Pathé Frères, created 1896. 
- Covidien and Tyco: Covidien was formed and spun off in 2007 from the healthcare division of the diversified conglomerate Tyco International. We took ADT (created 1887) as the ancestor company for the remaining Tyco International, and Kendall International (created 1903) as the ancestor company for Covidien.

- Monsanto and Pfizer: Monsanto (created 1901) was merged in 2000 into Pharmacia \& Upjohn (merged into Pfizer in 2003) but part of its earlier activities were spun off in 2002, also under the name Monsanto. We took 1901 as birth date for that new Monsanto company.

- CBS and Viacom: The present companies named Viacom and CBS result from a demerger in 2005 of Viacom, which itself was formed in 1971 as a division of CBS, became independent in 1973, and acquired its former parent CBS in 1999-2000. We traced the roots of the present-day Viacom to Paramount Pictures (created 1912), and of CBS to United Independent Broadcasters (created 1927).

- Banco Itau and Itausa: Banco Itau was created in 1964 by the merger between Banco Itau and Banco Federal de Credito (formerly Banco Central de Credito). As both Banco Itau and its parent holding company Itausa are in the FT Global 500 ranking of September 2007, we assigned 1943 (Banco Itau's creation) as the birth date for Itausa, and 1944 (Banco Central de Credito's creation) as that of Banco Itau.

- Standard Oil, JP Morgan, AT\&T: in three cases, different companies today result from a single initial company as a result of government-mandated breakups, all in the United States: Chevron and ExxonMobil from Standard Oil (created 1870); JPMorgan Chase and Morgan Stanley from JP Morgan (created 1871); and AT\&T and Verizon from 'Ma Bell' American Telegraph \& Telephone (created 1877). Thus, each of these three former groups appears twice in the dataset as 'ancestor' company.

Overall, we consider this methodology of assigning birth dates to be very robust. As previously mentioned (footnote 4), the one possible bias concerns the 35 companies (7\% of the total sample) for which we could not identify a single ancestor entity, and whose age may have been underestimated as a consequence.

\section{Regional and Country Demographics}

This section and the following ones provide a summary description of the patterns that result from a direct observation of birth dates as they appear in the dataset. This analysis is purely descriptive and does not aspire to explore causalities.

Birth dates can be summarised into 'population pyramids' which are constructed in a similar form as for national demographic studies. Table 5 presents the demographic composition of the entire sample, as well as the corresponding proportions of the sample's aggregate market capitalisation. 
Table 5

Age structure of the FT Global 500 sample at 30 September 2007

\begin{tabular}{|l|c|c|c|}
\hline Birth date & Number of companies & \% of total & \% of total market cap \\
\hline 1775 or earlier & 16 & $3.2 \%$ & $3.4 \%$ \\
\hline $1776-1800$ & 11 & $2.2 \%$ & $1.2 \%$ \\
\hline $1801-1825$ & 19 & $3.8 \%$ & $3.4 \%$ \\
\hline $1826-1850$ & 29 & $5.8 \%$ & $6.0 \%$ \\
\hline $1851-1875$ & 65 & $13.0 \%$ & $16.2 \%$ \\
\hline $1876-1900$ & 96 & $19.2 \%$ & $21.9 \%$ \\
\hline $1901-1925$ & 74 & $14.8 \%$ & $12.4 \%$ \\
\hline $1926-1950$ & 64 & $12.8 \%$ & $11.9 \%$ \\
\hline $1951-1975$ & 72 & $14.4 \%$ & $12.0 \%$ \\
\hline $1976-2000$ & 54 & $10.8 \%$ & $11.5 \%$ \\
\hline Total & 500 & $100.0 \%$ & $100.0 \%$ \\
\hline
\end{tabular}

The above table, however, masks broad differences in age distribution between different regions. Table 6 provides the 'population pyramids' for the main economic regions.

Table 6

Age structure of the FT Global 500 sample at 30 Sept 07, by region

\begin{tabular}{|l|c|c|c|c|c|c|}
\hline Birth date & Europe & US & Rest of World $\rightarrow$ & Japan & AU+CA & Emerging \\
\hline 1775 / earlier & $9 \%$ & $0 \%$ & $1 \%$ & $5 \%$ & $0 \%$ & $0 \%$ \\
\hline $1776-1800$ & $4 \%$ & $2 \%$ & $1 \%$ & $2 \%$ & $0 \%$ & $0 \%$ \\
\hline $1801-1825$ & $6 \%$ & $3 \%$ & $2 \%$ & $0 \%$ & $6 \%$ & $2 \%$ \\
\hline $1826-1850$ & $10 \%$ & $5 \%$ & $3 \%$ & $0 \%$ & $11 \%$ & $1 \%$ \\
\hline $1851-1875$ & $19 \%$ & $13 \%$ & $8 \%$ & $14 \%$ & $17 \%$ & $1 \%$ \\
\hline $1876-1900$ & $24 \%$ & $19 \%$ & $15 \%$ & $30 \%$ & $17 \%$ & $7 \%$ \\
\hline $1901-1925$ & $12 \%$ & $17 \%$ & $15 \%$ & $18 \%$ & $17 \%$ & $13 \%$ \\
\hline $1926-1950$ & $9 \%$ & $12 \%$ & $17 \%$ & $18 \%$ & $6 \%$ & $22 \%$ \\
\hline $1951-1975$ & $6 \%$ & $15 \%$ & $22 \%$ & $9 \%$ & $19 \%$ & $29 \%$ \\
\hline $1976-2000$ & $2 \%$ & $14 \%$ & $16 \%$ & $5 \%$ & $8 \%$ & $24 \%$ \\
\hline Total & $100 \%$ & $100 \%$ & $100 \%$ & $100 \%$ & $100 \%$ & $100 \%$ \\
\hline$\#$ companies & 156 & 178 & 166 & 44 & 36 & 86 \\
\hline
\end{tabular}

Some stylised facts emerge from this analysis:

- Since the Industrial Revolution, the US has never ceased to produce new champions. Specifically, $33 \%$ of its champions, representing $27.4 \%$ of the aggregate market 
capitalisation, were born after 1945; of these, 25 companies (14\% of US champions, representing $13 \%$ of aggregate market cap) were born in the last quarter of the $20^{\text {th }}$ century ${ }^{6}$.

- Most of Europe's champions date from before the first world war. Specifically, $78 \%$ of European companies in the sample (representing $81 \%$ of the corresponding aggregate market value) were created before 1914, and 90\% (representing 92\% of the market value) before 1939. Only 12 champions were created in Europe after 1950, and only 3 in the last quarter of the $20^{\text {th }}$ century ${ }^{7}$.

- Since the start of the Meiji era, Japan's demographic profile has not been markedly different from Europe's; only 2 of its companies were born after 1975, none of them an independent creation ${ }^{8}$.

- By contrast, champions from emerging countries display a remarkably young age distribution: $53 \%$ of them, representing $56 \%$ of aggregate market value, were born in the second half of the $20^{\text {th }}$ century; and 21 companies (24\% of total, representing $29 \%$ of total market value) in the last quarter of the $20^{\text {th }}$ centruy ${ }^{9}$.

Another way to display the same results is to look at the regional distribution of each age category, as is shown in Table 7. This illustrates, among other things, the fading of Europe as an incubator of new champions in the late $20^{\text {th }}$ century.

Table 7

Regional structure of each age category in the FT Global 500 sample (30/09/2007)

\begin{tabular}{|l|c|c|c|c|c|c|c|c|c|c|}
\hline & $\begin{array}{c}1775 / \\
\text { earlier }\end{array}$ & $\begin{array}{c}1776- \\
1800\end{array}$ & $\begin{array}{c}1801- \\
1825\end{array}$ & $\begin{array}{c}1826- \\
1850\end{array}$ & $\begin{array}{c}1851- \\
1875\end{array}$ & $\begin{array}{c}1876- \\
1900\end{array}$ & $\begin{array}{c}1901- \\
1925\end{array}$ & $\begin{array}{c}1926- \\
1950\end{array}$ & $\begin{array}{c}1951- \\
1975\end{array}$ & $\begin{array}{c}1976- \\
2000\end{array}$ \\
\hline Europe & $\mathbf{8 8 \%}$ & $\mathbf{5 5 \%}$ & $\mathbf{5 3 \%}$ & $\mathbf{5 2 \%}$ & $45 \%$ & $39 \%$ & $26 \%$ & $22 \%$ & $13 \%$ & $6 \%$ \\
\hline US & $0 \%$ & $36 \%$ & $26 \%$ & $31 \%$ & $35 \%$ & $35 \%$ & $41 \%$ & $33 \%$ & $\mathbf{3 8 \%}$ & $\mathbf{4 6 \%}$ \\
\hline Japan & $13 \%$ & $9 \%$ & $0 \%$ & $0 \%$ & $9 \%$ & $14 \%$ & $11 \%$ & $13 \%$ & $6 \%$ & $4 \%$ \\
\hline AU+CA & $0 \%$ & $0 \%$ & $11 \%$ & $14 \%$ & $9 \%$ & $6 \%$ & $8 \%$ & $3 \%$ & $10 \%$ & $6 \%$ \\
\hline Emerging & $0 \%$ & $0 \%$ & $11 \%$ & $3 \%$ & $2 \%$ & $6 \%$ & $15 \%$ & $\mathbf{3 0 \%}$ & $\mathbf{3 5 \%}$ & $\mathbf{3 9 \%}$ \\
\hline Total \% & $100 \%$ & $100 \%$ & $100 \%$ & $100 \%$ & $100 \%$ & $100 \%$ & $100 \%$ & $100 \%$ & $100 \%$ & $100 \%$ \\
\hline \# companies & 16 & 11 & 19 & 29 & 65 & 96 & 74 & 64 & 72 & 54 \\
\hline
\end{tabular}

\footnotetext{
${ }^{6}$ Apple, Genentech, Unitedhealth, Oracle, Home Depot, Boston Scientific, EMC, Amgen, Time Warner Cable, DirecTV, Adobe Systems, Costco Wholesale, Cisco Systems, Dell, Qualcomm, XTO Energy, Celgene, Weatherford International, Gilead Sciences, Capital One Financial, Garmin, Amazon.com, Yahoo!, eBay, and Google.

${ }^{7}$ BskyB, Vodafone, and Renewable Energy Corporation.

${ }^{8}$ NTT DoCoMo and Yahoo! Japan.

${ }^{9}$ Sabic, Etisalat, Infosys, CNOOC, ICBC, China Shenhua Energy, Bharti Airtel, China Merchants Bank, China Citic Bank, Taiwan Semiconductor Manufacturing, Ping An Insurance, América Movil, VTB Bank, China Mobile, Vimpelcom, Datang International Power Generation, China Unicom, Huaneng Power International, MTN Group, Country Garden, and Reliance Communications.
} 
Table 8 presents a more detailed demographic picture of Europe's champions, divided into 6 geographical groupings. The differences among European sub-regions are not very marked, even though the numbers may be rendered less significant by the relatively small size of the corresponding samples.

Table 8

Age structure of European companies in the FT Global 500 sample at 30 Sept 07

\begin{tabular}{|l|c|c|c|c|c|c|}
\hline Birth date & Nordics & UK/IE & Germany & France & IT/ES/PT/GR & Others \\
\hline 1775 / earlier & $0 \%$ & $14 \%$ & $10 \%$ & $6 \%$ & $15 \%$ & $6 \%$ \\
\hline $1776-1800$ & $0 \%$ & $11 \%$ & $0 \%$ & $3 \%$ & $0 \%$ & $3 \%$ \\
\hline $1801-1825$ & $11 \%$ & $9 \%$ & $5 \%$ & $6 \%$ & $0 \%$ & $6 \%$ \\
\hline $1826-1850$ & $0 \%$ & $9 \%$ & $10 \%$ & $13 \%$ & $15 \%$ & $10 \%$ \\
\hline $1851-1875$ & $39 \%$ & $14 \%$ & $20 \%$ & $9 \%$ & $10 \%$ & $26 \%$ \\
\hline $1876-1900$ & $6 \%$ & $14 \%$ & $35 \%$ & $31 \%$ & $25 \%$ & $29 \%$ \\
\hline $1901-1925$ & $22 \%$ & $14 \%$ & $5 \%$ & $16 \%$ & $10 \%$ & $6 \%$ \\
\hline $1926-1950$ & $11 \%$ & $6 \%$ & $5 \%$ & $3 \%$ & $20 \%$ & $13 \%$ \\
\hline $1951-1975$ & $6 \%$ & $3 \%$ & $10 \%$ & $13 \%$ & $5 \%$ & $0 \%$ \\
\hline $1976-2000$ & $6 \%$ & $6 \%$ & $0 \%$ & $0 \%$ & $0 \%$ & $0 \%$ \\
\hline Total & $100 \%$ & $100 \%$ & $100 \%$ & $100 \%$ & $100 \%$ & $100 \%$ \\
\hline$\#$ companies & 18 & 35 & 20 & 32 & 20 & 31 \\
\hline
\end{tabular}

\section{Sectoral demographics}

The analysis by sector reflects successive waves of new technology and business development. Table 9 presents the corresponding figures.

Table 9

Age structure of the FT Global 500 sample at 30 Sept 07, by sector

N.B. the sector refers to the companies' current sector (as of September 2007), irrespective of the nature of their activity at the time of birth or in the development of their corporate history.

\begin{tabular}{|l|c|c|c|c|c|}
\hline Birth date & $\begin{array}{c}\text { Banking and } \\
\text { Finance }\end{array}$ & $\begin{array}{c}\text { Business } \\
\text { Services }\end{array}$ & $\begin{array}{c}\text { Consumer } \\
\text { Products and } \\
\text { Services }\end{array}$ & $\begin{array}{c}\text { Energy } \\
\text { Services and } \\
\text { Utilities }\end{array}$ & $\begin{array}{c}\text { Health and } \\
\text { Life Sciences }\end{array}$ \\
\hline 1775 / earlier & $7 \%$ & $14 \%$ & $5 \%$ & $0 \%$ & $3 \%$ \\
\hline $1776-1800$ & $4 \%$ & $0 \%$ & $5 \%$ & $3 \%$ & $3 \%$ \\
\hline $1801-1825$ & $9 \%$ & $0 \%$ & $3 \%$ & $6 \%$ & $3 \%$ \\
\hline $1826-1850$ & $7 \%$ & $10 \%$ & $5 \%$ & $3 \%$ & $3 \%$ \\
\hline $1851-1875$ & $\mathbf{2 2 \%}$ & $14 \%$ & $12 \%$ & $3 \%$ & $6 \%$ \\
\hline
\end{tabular}




\begin{tabular}{|l|c|c|c|c|c|}
\hline $1876-1900$ & $12 \%$ & $5 \%$ & $14 \%$ & $\mathbf{5 6 \%}$ & $\mathbf{2 7 \%}$ \\
\hline $1901-1925$ & $7 \%$ & $10 \%$ & $\mathbf{2 0 \%}$ & $\mathbf{1 6 \%}$ & $\mathbf{1 8 \%}$ \\
\hline $1926-1950$ & $13 \%$ & $5 \%$ & $11 \%$ & $3 \%$ & $15 \%$ \\
\hline $1951-1975$ & $13 \%$ & $\mathbf{2 9 \%}$ & $\mathbf{2 0} \%$ & $3 \%$ & $3 \%$ \\
\hline $1976-2000$ & $6 \%$ & $14 \%$ & $8 \%$ & $6 \%$ & $\mathbf{1 8 \%}$ \\
\hline Total & $100 \%$ & $100 \%$ & $100 \%$ & $100 \%$ & $100 \%$ \\
\hline \# companies & 109 & 21 & 66 & 32 & 33 \\
\hline
\end{tabular}

\begin{tabular}{|l|c|c|c|c|}
\hline Birth date & Insurance & Manufacturing & Oil, Gas and Mining & Telecoms \& Media \\
\hline 1775 / earlier & $0 \%$ & $1 \%$ & $0 \%$ & $0 \%$ \\
\hline $1776-1800$ & $4 \%$ & $1 \%$ & $0 \%$ & $0 \%$ \\
\hline $1801-1825$ & $7 \%$ & $2 \%$ & $0 \%$ & $0 \%$ \\
\hline $1826-1850$ & $\mathbf{1 8 \%}$ & $7 \%$ & $10 \%$ & $2 \%$ \\
\hline $1851-1875$ & $\mathbf{2 1 \%}$ & $11 \%$ & $6 \%$ & $\mathbf{2 9 \%}$ \\
\hline $1876-1900$ & $\mathbf{3 2 \%}$ & $\mathbf{1 8 \%}$ & $18 \%$ & $10 \%$ \\
\hline $1901-1925$ & $4 \%$ & $\mathbf{2 2 \%}$ & $\mathbf{2 2 \%}$ & $8 \%$ \\
\hline $1926-1950$ & $4 \%$ & $\mathbf{1 8 \%}$ & $\mathbf{3 3 \%}$ & $8 \%$ \\
\hline $1951-1975$ & $7 \%$ & $13 \%$ & $10 \%$ & $\mathbf{3 3 \%}$ \\
\hline $1976-2000$ & $4 \%$ & $9 \%$ & $100 \%$ & $100 \%$ \\
\hline Total & $100 \%$ & $100 \%$ & 49 & 48 \\
\hline$\#$ companies & 28 & 114 & & \\
\hline
\end{tabular}

These numbers reflect the diverse industry dynamics:

- In the Banking \& Finance sector (which also includes real estate and holding companies), new champions have appeared in every time period, though obviously at different moments in different regions: 15 of the 24 champions born in this sector after 1945 are from emerging countries.

- Business Services include (generally old) transport companies, and a significant number of software and professional services companies born in recent decades.

- Creation of new champions in Consumer Products and Services has been dynamic throughout the time since the emergence of mass consumer markets in the late $19^{\text {th }}$ century.

- Global champions in the Energy Services and Utilities sector almost all trace their roots to the second industrial revolution: 66\% of them were born in the three decades from 1880 to 1910.

- The Health and Life Sciences sector displays two waves of champion creation which may be linked to the advent of specialty chemicals from 1875 to 1950, and biotechnology development since 1975.

- Almost all Insurance champions (23 out of 28 companies) were born before 1900. 
- The Manufacturing sector (which includes low-tech as well as high-tech activities) has generated new champions continuously since the 1830s, with a peak at the beginning of the $20^{\text {th }}$ century.

- The Oil, Gas and Mining sector is almost entirely a creation of the $20^{\text {th }}$ century: only $16 \%$ of the companies were created before 1900 , and no fewer than $43 \%$ were born after 1950 , more than half of which in emerging countries and Canada.

- The Telecoms and Media sector also has two waves, corresponding to the respective emergence of fixed telephony, and mobile networks and the internet: $63 \%$ of its companies were born either in 1876-1900 or in 1976-2000.

An alternative way to look at the same picture is to observe the sectoral mix of each age category. This is done in Table 10.

Table 10

Sector structure of each age category in the FT Global 500 sample at 30 Sept 07

\begin{tabular}{|l|c|c|c|c|c|c|c|c|c|c|}
\hline & $\begin{array}{l}1775 / \\
\text { earlier }\end{array}$ & $\begin{array}{c}1776- \\
1800\end{array}$ & $\begin{array}{c}1801- \\
1825\end{array}$ & $\begin{array}{c}1826- \\
1850\end{array}$ & $\begin{array}{c}1851- \\
1875\end{array}$ & $\begin{array}{c}1876- \\
1900\end{array}$ & $\begin{array}{c}1901- \\
1925\end{array}$ & $\begin{array}{c}1926- \\
1950\end{array}$ & $\begin{array}{c}1951- \\
1975\end{array}$ & $\begin{array}{c}1976- \\
2000\end{array}$ \\
\hline $\begin{array}{l}\text { Banking and } \\
\text { Finance }\end{array}$ & $\mathbf{5 0 \%}$ & $\mathbf{3 6 \%}$ & $\mathbf{5 3 \%}$ & $\mathbf{2 8 \%}$ & $\mathbf{3 7 \%}$ & $14 \%$ & $11 \%$ & $22 \%$ & $19 \%$ & $11 \%$ \\
\hline Business Services & $\mathbf{1 9 \%}$ & $0 \%$ & $0 \%$ & $7 \%$ & $5 \%$ & $1 \%$ & $3 \%$ & $2 \%$ & $8 \%$ & $6 \%$ \\
\hline $\begin{array}{l}\text { Consumer Products } \\
\text { and Services }\end{array}$ & $19 \%$ & $\mathbf{2 7 \%}$ & $11 \%$ & $10 \%$ & $12 \%$ & $9 \%$ & $18 \%$ & $11 \%$ & $18 \%$ & $9 \%$ \\
\hline $\begin{array}{l}\text { Energy Services } \\
\text { and Utilities }\end{array}$ & $0 \%$ & $9 \%$ & $11 \%$ & $3 \%$ & $2 \%$ & $\mathbf{1 9 \%}$ & $7 \%$ & $2 \%$ & $1 \%$ & $4 \%$ \\
\hline $\begin{array}{l}\text { Health and Life } \\
\text { Sciences }\end{array}$ & $6 \%$ & $9 \%$ & $5 \%$ & $3 \%$ & $3 \%$ & $9 \%$ & $8 \%$ & $8 \%$ & $1 \%$ & $\mathbf{1 1 \%}$ \\
\hline Insurance & $0 \%$ & $9 \%$ & $11 \%$ & $\mathbf{1 7 \%}$ & $9 \%$ & $9 \%$ & $1 \%$ & $2 \%$ & $3 \%$ & $2 \%$ \\
\hline Manufacturing & $6 \%$ & $9 \%$ & $11 \%$ & $\mathbf{2 8 \%}$ & $18 \%$ & $21 \%$ & $\mathbf{3 4 \%}$ & $\mathbf{3 1 \%}$ & $21 \%$ & $19 \%$ \\
\hline $\begin{array}{l}\text { Oil, Gas and } \\
\text { Mining }\end{array}$ & $0 \%$ & $0 \%$ & $0 \%$ & $0 \%$ & $8 \%$ & $3 \%$ & $12 \%$ & $\mathbf{1 7 \%}$ & $\mathbf{2 2 \%}$ & $9 \%$ \\
\hline $\begin{array}{l}\text { Telecoms and } \\
\text { Media }\end{array}$ & $0 \%$ & $0 \%$ & $0 \%$ & $3 \%$ & $6 \%$ & $\mathbf{1 5 \%}$ & $7 \%$ & $6 \%$ & $6 \%$ & $\mathbf{3 0 \%}$ \\
\hline Total \% & $100 \%$ & $100 \%$ & $100 \%$ & $100 \%$ & $100 \%$ & $100 \%$ & $100 \%$ & $100 \%$ & $100 \%$ & $100 \%$ \\
\hline \# companies & 16 & 11 & 19 & 29 & 65 & 96 & 74 & 64 & 72 & 54 \\
\hline
\end{tabular}

\section{Conclusion and policy implications}

Our dataset sheds new light on the 500 largest companies worldwide by systematically documenting their date of creation using a consistent methodology. While a few individual cases are a matter of judgment, the overall picture is robust and provides a striking illustration of the respective performance of different global regions when it comes to large-scale corporate development. 
Further work may be embarked upon by other scholars on the basis of this dataset, which is why it is made publicly available on the internet. In particular, it might be worthwhile to correlate birth dates with other features of companies or of their sectors or countries/regions, such as legal origin as in the so-called law and economics literature, or other characteristics of national financial systems.

The section of our data perhaps of most immediate interest to policymakers is the one which covers the most recent period, specifically the global champions born in the second half of the $20^{\text {th }}$ century. This is marked by the continuous appearance of new champions in the US; a growing number of new champions in emerging countries; and very few new champions in Europe and Japan.

As argued in Philippon and Véron (2008), the near-absence of new champions from Europe and Japan warrants concern on the part of policymakers in these two regions, because of the increasingly Schumpeterian growth regime of today's developed economies. This growth regime implies that economic welfare is unlikely to be maximised if all or even most new business developments are conducted within long-established corporate entities.

Europe and Japan cannot emulate the strong catch-up growth observed in emerging countries which is at the origin of most of their new champions, nor can it generally rely on preferential access to commodities as in many emerging countries, Australia, Canada, and (to a lesser extent) the US. Therefore, the most relevant existing template showing which companies might have been born in Europe or Japan if policies had been different is to be found in the 47 non-oil new champions born in the US after 1950.

These are predominantly composed of two groups of similar size: 20 high-technology firms (in electronics, medical technology, software, biotech, and internet services), and 23 services companies (in finance, retail, entertainment, business services, and health services). Thus, our dataset appears compatible with the proposition that policies that focus on, respectively, enabling the emergence of innovation ecosystems (to drive high-technology start-ups), and on unleashing the growth potential of services sectors, are likely to help Europe and Japan regain some of their ability to generate new global corporate champions.

\section{References}

Berger, Suzanne (2005) How We Compete: What Companies Around the World Are Doing to Make It in Today's Global Economy. New York: Doubleday

Field, Laura and Karpoff, Jonathan (2002) 'Takeover Defenses of IPO Firms' Journal of Finance 57 (5): 1857-1889, October

Jovanovic, Boyan and Rousseau, Peter (2001) 'Why Wait? A Century of Life before IPO', NBER Working Paper 8081, January

Loughran, Tim and Ritter, Jay (2004) 'Why Has IPO Underpricing Changed Over Time?' Financial Management 33(3): 5-37, Autumn

Philippon, Thomas and Véron, Nicolas (2008) 'Financing Europe’s Fast Movers' Bruegel Policy Brief 2008/01, January 


\section{Appendix}

\section{Birth Dates and Origins for the FT Global 500 Ranking, 30 September 2007}

\begin{tabular}{|c|c|c|c|c|c|}
\hline Rank Company & Country & Sector & $\begin{array}{r}\text { Market Cap } \\
30 / 09 / 2007 \\
\$ \mathrm{~m}\end{array}$ & $\begin{array}{l}\text { Birth Name at creation } \\
\text { Date }\end{array}$ & Place of creation \\
\hline 1 Exxon Mobil & US & Oil, Gas and Mining & 513,362 & 1870 Standard Oil & Cleveland $\mathrm{OH}$ \\
\hline 3 China Mobile & Hong Kong & Telecoms and Media & 327,937 & $\begin{array}{l}1990 \text { [China Mobile created in } 1997 \text { from existing } \\
\text { assets] }\end{array}$ & Hong Kong, HK \\
\hline $\begin{array}{l}4 \text { Indl.\& Coml.Bank of } \\
\text { China }\end{array}$ & China & Banking and Finance & 279,269 & 1984 ICBC & Beijing, CN \\
\hline 7 Gazprom & Russia & Oil, Gas and Mining & 260,249 & 1941 Elshanka gas well & Saratov, RU \\
\hline 8 AT\&T & US & Telecoms and Media & 258,047 & 1877 National Bell Telephone Company & New York NY \\
\hline 9 Citigroup & US & Banking and Finance & 232,162 & 1812 First National City Bank of New York & New York NY \\
\hline 10 Bank of America & US & Banking and Finance & 223,066 & 1874 Commercial National Bank & Charlotte NC \\
\hline $11 \mathrm{BP}$ & UK & Oil, Gas and Mining & 220,020 & 1909 Anglo-Persian Oil Company & London, UK \\
\hline 12 Procter \& Gamble & US & Consumer Products \& Serv. & 219,514 & 1837 Procter \& Gamble & Cincinnati $\mathrm{OH}$ \\
\hline $13 \mathrm{HSBC}$ & UK & Banking and Finance & 216,951 & $\begin{array}{l}1865 \text { Hongkong and Shanghai Banking Company } \\
\text { Limited }\end{array}$ & Hong Kong, HK \\
\hline 16 BHP Billiton & Australia & Oil, Gas and Mining & 214,446 & 1860 Billiton plc & London, UK \\
\hline 17 Toyota Motor & Japan & Manufacturing & 212,805 & 1926 Toyoda Automatic Loom Works, Ltd & Kariya, JP \\
\hline 18 Cisco Systems & US & Manufacturing & 201,790 & 1984 Cisco Systems & San José CA \\
\hline 19 Chevron & US & Oil, Gas and Mining & 199,485 & 1870 Standard Oil & Cleveland $\mathrm{OH}$ \\
\hline 20 Sinopec & China & Oil, Gas and Mining & 197,406 & $\begin{array}{l}1930 \text { [China Petroleum and Chemical Corp created } \\
2000 \text { from existing assets] }\end{array}$ & Beijing, CN \\
\hline 21 Total & France & Oil, Gas and Mining & 194,034 & 1924 Compagnie française des pétroles & Paris, FR \\
\hline 22 EDF & France & Energy Services and Utilities & 192,155 & $\begin{array}{l}1890 \text { [Electricité de France created in } 1946 \text { from } \\
\text { existing assets] }\end{array}$ & Paris, FR \\
\hline 23 Vodafone Group & UK & Telecoms and Media & 190,753 & 1983 Racal Telecom & London, UK \\
\hline 24 Johnson \& Johnson & US & Health and Life Sciences & 190,169 & 1886 Johnson \& Johnson & New Brunswick NJ \\
\hline 25 Berkshire Hathaway & US & Insurance & 183,413 & 1888 Hathaway Manufacturing Company & New Bedford MA \\
\hline 26 Bank of China & China & Banking and Finance & 181,189 & 1912 Bank of China & Hong Kong, HK \\
\hline 27 Wal-Mart Stores & US & Consumer Products \& Serv. & 177,578 & 1962 Wal-Mart Discount City & Rogers AR \\
\hline 28 Nestle & Switzerland & Consumer Products \& Serv. & 175,980 & 1866 Nestle & Vevey, $\mathrm{CH}$ \\
\hline 38 Glaxosmithkline & UK & Health and Life Sciences & 148,203 & 1880 Burroughs Wellcome \& Company & London, UK \\
\hline $39 \mathrm{Eni}$ & Italy & Oil, Gas and Mining & 148,047 & 1926 Agip & Rome, IT \\
\hline 40 Altria Group & US & Consumer Products \& Serv. & 146,375 & 1847 Philip Morris & London, UK \\
\hline 41 Novartis & Switzerland & Health and Life Sciences & 144,204 & 1758 J. R. Geigy & Basel, $\mathrm{CH}$ \\
\hline 42 ConocoPhillips & US & Oil, Gas and Mining & 142,818 & 1875 Continental Oil and Transportation Company & Ogden UT \\
\hline 43 Apple & us & Manufacturing & 133,464 & 1976 Apple Computer, Inc. & Cupertino CA \\
\hline 44 Telefonica & Spain & Telecoms and Media & 133,263 & $\begin{array}{l}1885 \text { [Telefónica, S.A. created in } 1924 \text { from existing } \\
\text { assets] }\end{array}$ & Madrid, ES \\
\hline 45 Coca-Cola & us & Consumer Products \& Serv. & 132,961 & 1885 Coca-Cola & Covington GA \\
\hline 46 Google & US & Telecoms and Media & 132,118 & 1998 Google & Menlo Park CA \\
\hline 47 Rio Tinto & UK & Oil, Gas and Mining & 129,633 & 1873 Rio Tinto mines & London, UK \\
\hline $\begin{array}{l}48 \text { Verizon } \\
\text { Communications }\end{array}$ & US & Telecoms and Media & 128,524 & 1877 National Bell Telephone Company & New York NY \\
\hline 49 Hewlett-Packard & US & Manufacturing & 128,362 & 1939 Hewlett-Packard Company & Palo Alto CA \\
\hline $50 \mathrm{EOn}$ & Germany & Energy Services and Utilities & 127,604 & $\begin{array}{l}1880 \text { [Vereinigte Industrieunternehmen AG created } \\
\text { in } 1923 \text { from existing assets] }\end{array}$ & Berlin, DE \\
\hline 51 Schlumberger & US & Manufacturing & 125,166 & 1926 Société de Prospection Électrique & Paris, FR \\
\hline 52 Siemens & Germany & Manufacturing & 122,894 & 1847 Siemens & Berlin, DE \\
\hline 53 Ping An Insurance & China & Insurance & 121,492 & 1988 Ping An Insurance (Group) Company of China & Shenzhen, CN \\
\hline 54 Banco Santander & Spain & Banking and Finance & 121,234 & 1857 Banco de Santander & Santander, ES \\
\hline 55 Wells Fargo \& Co & us & Banking and Finance & 119,058 & 1852 Wells, Fargo \& Company & New York NY \\
\hline 56 Pepsico & US & Consumer Products \& Serv. & 118,373 & 1898 Pepsi Cola Company & Purchase NY \\
\hline 57 Sanofi-Aventis & France & Health and Life Sciences & 115,024 & 1863 Hoechst & Frankfurt, DE \\
\hline 58 Merck & US & Health and Life Sciences & 112,119 & 1891 Merck \& Co & Whitehouse Station NJ \\
\hline 59 ArcelorMittal & Netherlands & Manufacturing & 111,558 & $\begin{array}{l}1882 \text { Société Anonyme des Hauts Fourneaux et } \\
\text { Forges de Dudelange }\end{array}$ & Dudelange, LU \\
\hline 60 UBS & Switzerland & Banking and Finance & 111,114 & 1856 Basler Bankverein & Basel, $\mathrm{CH}$ \\
\hline
\end{tabular}




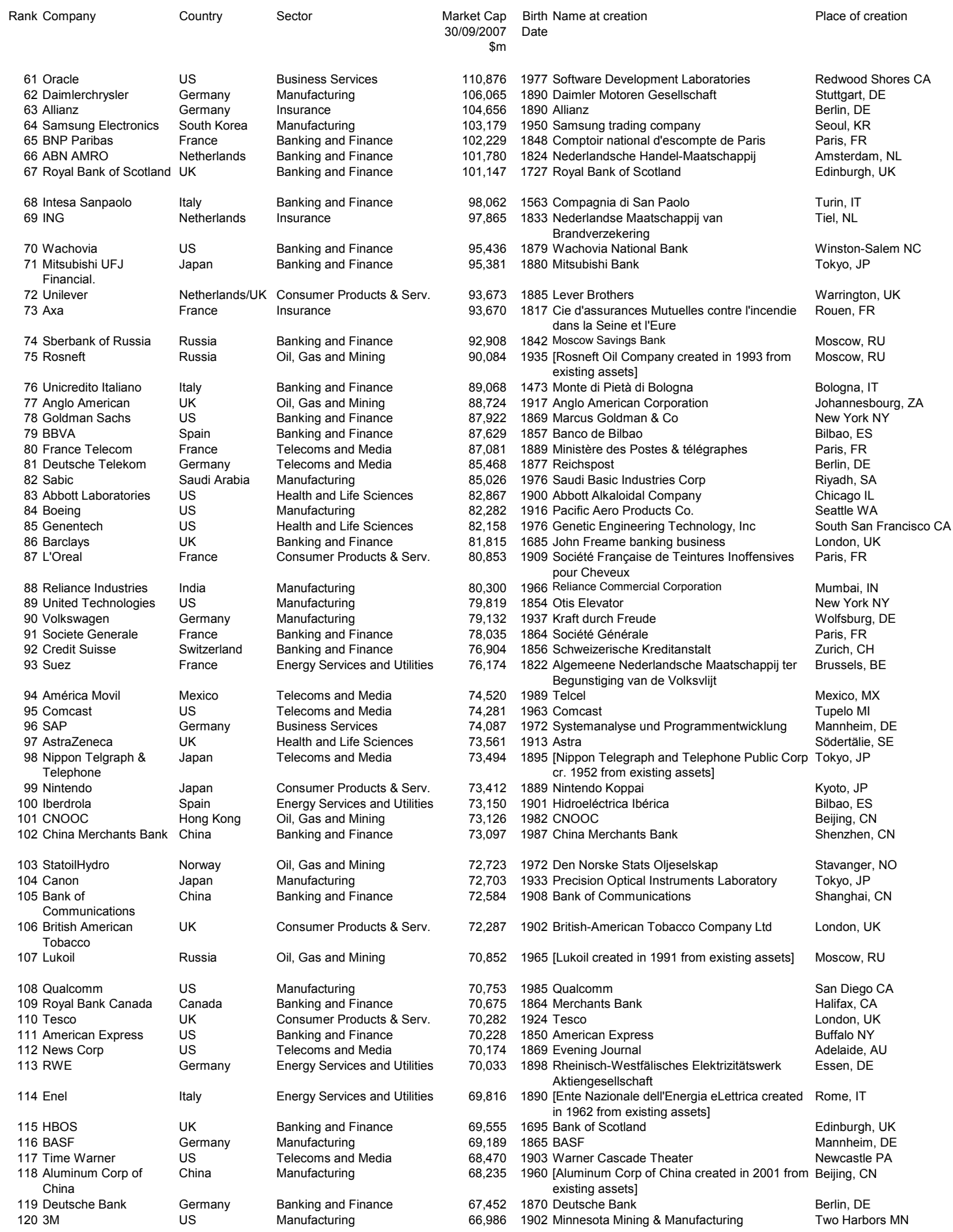




\begin{tabular}{|c|c|c|c|c|c|}
\hline Rank Company & Country & Sector & $\begin{array}{r}\text { Market Cap } \\
30 / 09 / 2007 \\
\$ \mathrm{~m}\end{array}$ & $\begin{array}{l}\text { Birth Name at creation } \\
\text { Date }\end{array}$ & Place of creation \\
\hline 121 Morgan Stanley & US & Banking and Finance & 66,934 & 1871 Drexel, Morgan \& Company & New York NY \\
\hline 122 Walt Disney & US & Telecoms and Media & 66,748 & 1922 Walt Disney Company & Burbank CA \\
\hline 123 NTT Docomo & Japan & Telecoms and Media & 65,420 & 1991 NTT DoCoMo & Tokyo, JP \\
\hline 124 McDonalds & US & Consumer Products \& Serv. & 64,916 & 1940 McDonald's Restaurant & San Bernardino CA \\
\hline $\begin{array}{l}125 \text { Commonwealth Bk of } \\
\text { Australia }\end{array}$ & Australia & Banking and Finance & 64,901 & 1911 Commonwealth Bank & Melbourne, AU \\
\hline 126 Mizuho Financial & Japan & Banking and Finance & 64,901 & 1873 Dai-ichi Bank, Ltd & Tokyo, JP \\
\hline 127 Eli Lilly & US & Health and Life Sciences & 64,575 & 1876 Eli Lilly \& Co & Indianapolis IN \\
\hline 128 Ericsson & Sweden & Manufacturing & 64,290 & 1876 L M Ericsson & Stockholm, SE \\
\hline 129 Xstrata & UK & Oil, Gas and Mining & 64,219 & 1928 Falconbridge Nickel Mines Limited & Sudbury, CA \\
\hline 130 Unitedhealth & us & Health and Life Sciences & 64,164 & 1977 UnitedHealthCare Corporation & Minnetonka MN \\
\hline 131 Posco & South Korea & Manufacturing & 64,117 & 1968 Pohang Iron and Steel Company & Pohang, KR \\
\hline 132 Home Depot & US & Consumer Products \& Serv. & 64,041 & 1978 Home Depot & Atlanta GA \\
\hline 133 Medtronic & US & Health and Life Sciences & 63,976 & 1949 Medtronic & Minneapolis MN \\
\hline 134 Fortis & Belgium & Banking and Finance & 63,881 & 1934 Generale Bank & Brussels, BE \\
\hline 135 Credit Agricole & France & Banking and Finance & 63,362 & 1894 Crédit Agricole Mutuel & Paris, FR \\
\hline 136 Manulife Financial & Canada & Insurance & 62,747 & 1887 The Manufacturers Life Insurance Company & Toronto, CA \\
\hline 137 Dell & US & Manufacturing & 62,697 & 1984 PCs Ltd & Austin TX \\
\hline 138 Takeda Pharmaceutical & Japan & Health and Life Sciences & 62,473 & 1781 Takeda & Osaka, JP \\
\hline 139 Lloyds TSB & UK & Banking and Finance & 62,384 & 1765 Taylor's and Lloyds & Birmingham, UK \\
\hline 140 Generali & Italy & Insurance & 61,731 & $\begin{array}{l}1831 \text { Imperial Regia Privilegiata Compagnia di } \\
\text { Assicurazioni Generali Austro-Italiche }\end{array}$ & Trieste, IT \\
\hline 141 Honda Motor & Japan & Manufacturing & 61,578 & 1948 Honda Motor Co & Tokyo, JP \\
\hline 142 Amgen & US & Health and Life Sciences & 61,477 & 1980 Applied Molecular Genetics & Thousand Oaks CA \\
\hline 143 Merrill Lynch & US & Banking and Finance & 61,250 & 1914 Charles E. Merrill \& Co. & New York NY \\
\hline 144 Bayer & Germany & Manufacturing & 60,678 & 1863 Bayer & Leverkusen, DE \\
\hline 145 Endesa & Spain & Energy Services and Utilities & 60,365 & 1944 Empresa Nacional de Electricidad, S.A. & Madrid, ES \\
\hline $146 \mathrm{ABB}$ & Switzerland & Manufacturing & 60,256 & 1883 ASEA & Stockholm, SE \\
\hline $\begin{array}{l}147 \text { Sumitomo Mitsui } \\
\text { Financial }\end{array}$ & Japan & Banking and Finance & 60,180 & 1876 Mitsui Bank & Tokyo, JP \\
\hline 148 Wyeth & US & Health and Life Sciences & 59,904 & 1860 Wyeth Drugstore & Philadelphia PA \\
\hline 149 A P Moller - Maersk & Denmark & Business Services & 59,884 & 1904 Steamship Company Svendborg & Copenhagen, DK \\
\hline 150 Fannie Mae & US & Banking and Finance & 59,196 & 1938 Federal National Mortgage Association & Washington DC \\
\hline 151 Banco Itau & Brazil & Banking and Finance & 59,109 & 1943 Banco Central de Crédito & Sao Paolo, BR \\
\hline 152 CVS Caremark & US & Consumer Products \& Serv. & 58,688 & 1963 Consumer Value Stores & Lowell MA \\
\hline 153 LVMH & France & Consumer Products \& Serv. & 58,578 & 1743 Champagne Moët & Epernay, FR \\
\hline 154 BG Group & UK & Oil, Gas and Mining & 58,006 & $\begin{array}{l}1967 \text { Start of exploitation of natural gas in the UK } \\
\text { north sea }\end{array}$ & London, UK \\
\hline 155 Bradesco & Brazil & Banking and Finance & 57,785 & 1943 Banco Brasileiro de Descontos & Marilia, BR \\
\hline 156 Diageo & UK & Consumer Products \& Serv. & 57,245 & 1759 Arthur Guinness Brewery & Dublin, IE \\
\hline 157 National Australia Bank & Australia & Banking and Finance & 57,169 & 1834 Commercial Banking Company of Sidney & Sidney, AU \\
\hline 158 Bristol Myers Squibb & us & Health and Life Sciences & 57,003 & 1887 Bristol-Myers Company & Clinton NY \\
\hline 159 US Bancorp & US & Banking and Finance & 56,161 & 1890 U.S. Bancorp & Portland OR \\
\hline 160 Norsk Hydro & Norway & Manufacturing & 55,996 & 1905 Norsk hydro-elektrisk Kvælstofaktieselskab & Oslo, NO \\
\hline 161 Inbev & Belgium & Consumer Products \& Serv. & 55,462 & 1708 Sebastien Artois master brewer in Leuven & Leuven, BE \\
\hline 162 Toronto-Dominion Bank & Canada & Banking and Finance & 55,229 & 1855 Bank of Toronto & Toronto, CA \\
\hline 163 Telecom Italia & Italy & Telecoms and Media & 55,073 & $\begin{array}{l}1890 \text { [Società Idroelettrica Piemontese created in } \\
1918 \text { from existing assets] }\end{array}$ & Turin, IT \\
\hline 164 Research In Motion & Canada & Manufacturing & 54,949 & 1984 Research In Motion & Waterloo, CA \\
\hline 165 Japan Tobacco & Japan & Consumer Products \& Serv. & 54,862 & $\begin{array}{l}1898 \text { Japan Tobacco and Salt Public Corporation } \\
\text { (1949) }\end{array}$ & Tokyo, JP \\
\hline 166 Kraft Foods & us & Consumer Products \& Serv. & 54,412 & 1903 Kraft Cheese & Northfield IL \\
\hline 167 Surgutneftegas & Russia & Oil, Gas and Mining & 54,142 & $\begin{array}{l}1961 \text { [Rinef refinery created in } 1993 \text { from existing } \\
\text { assets] }\end{array}$ & Kirishi, RU \\
\hline 168 Target & US & Consumer Products \& Serv. & 53,819 & 1902 Dayton's department store & Minneapolis MN \\
\hline 169 Mitsubishi & Japan & Business Services & 53,507 & 1870 Mitsubishi Shokai & Tokyo, JP \\
\hline 170 Occidental Petroleum & US & Oil, Gas and Mining & 53,234 & 1920 Occidental Petroleum & Los Angeles CA \\
\hline 171 Ebay & us & Consumer Products \& Serv. & 53,007 & 1995 AuctionWeb & San José CA \\
\hline 172 Sprint Nextel & US & Telecoms and Media & 52,664 & 1899 Brown Telephone Company & Abilene KA \\
\hline 173 Texas Instruments & US & Manufacturing & 52,290 & 1930 Geophysical Service Inc & Dallas TX \\
\hline 174 Unified Energy System & Russia & Energy Services and Utilities & 52,055 & $\begin{array}{l}1890 \text { [Unified Energy System of Russia } \\
\text { created in } 1992 \text { from existing assets] }\end{array}$ & Moscow, RU \\
\hline 175 Metlife & US & Insurance & 51,800 & 1868 Metropolitan Life Insurance Compan & New York NY \\
\hline 176 Bank of Nova Scotia & Canada & Banking and Finance & 51,653 & 1832 Bank of Nova Scotia & Halifax, CA \\
\hline $\begin{array}{l}177 \text { Taiwan Semiconductor } \\
\text { Manufacturing }\end{array}$ & Taiwan & Manufacturing & 51,494 & 1987 TSMC & Hsinchu, TW \\
\hline 178 Philips & Netherlands & Manufacturing & 51,441 & 1891 Philips & Eindhoven, NL \\
\hline 179 Oil \& Natural Gas & India & Oil, Gas and Mining & 51,417 & $\begin{array}{l}1920 \text { [Oil and Natural Gas Corporation Limited } \\
\text { created in } 1956 \text { from existing assets] }\end{array}$ & Dehradun, IN \\
\hline 180 United Parcel Services & us & Business Services & 51,217 & 1907 American Messenger Company & Seattle WA \\
\hline
\end{tabular}




\begin{tabular}{|c|c|c|c|c|c|}
\hline Rank Company & Country & Sector & $\begin{array}{r}\text { Market Cap } \\
30 / 09 / 2007 \\
\$ \mathrm{~m}\end{array}$ & $\begin{array}{l}\text { Birth Name at creation } \\
\text { Date }\end{array}$ & Place of creation \\
\hline 181 Gaz de France & France & Energy Services and Utilities & 50,988 & $\begin{array}{l}1895 \text { [Gaz de France created in } 1946 \text { from existing } \\
\text { assets] }\end{array}$ & Paris, FR \\
\hline 182 BT Group & UK & Telecoms and Media & 50,565 & 1846 Electric Telegraph Company & London, UK \\
\hline 183 Exelon & US & Energy Services and Utilities & 50,503 & 1881 Philadelphia Electric Company & Philadelphia PA \\
\hline 184 Caterpillar & US & Manufacturing & 50,129 & 1890 Holt Manufactoring Company & Stockton CA \\
\hline $\begin{array}{l}185 \text { Bank of New York } \\
\text { Mellon }\end{array}$ & US & Banking and Finance & 49,963 & 1794 Bank of New York & New York NY \\
\hline 186 Carrefour & France & Consumer Products \& Serv. & 49,253 & 1957 Carrefour & Annecy, FR \\
\hline 187 ANZ Banking & Australia & Banking and Finance & 49,008 & 1837 The Bank of Australasia & London, UK \\
\hline 188 Vivendi & France & Telecoms and Media & 48,987 & 1896 Pathé Frères & Paris, FR \\
\hline 189 Nippon Steel & Japan & Manufacturing & 48,945 & 1896 Imperial Japanese Government Steel Works & Yawata, JP \\
\hline 190 China Citic Bank & China & Banking and Finance & 48,847 & 1987 CITIC Industrial Bank & Beijing, CN \\
\hline 191 MMC Norilsk Nickel & Russia & Manufacturing & 48,801 & 1935 Norilsk Combinat & Norilsk, RU \\
\hline 192 KBC Groupe & Belgium & Banking and Finance & 48,708 & $\begin{array}{l}1889 \text { Algemeene Bankvereeniging en Volksbank } \\
\text { van Leuven }\end{array}$ & Leuven, BE \\
\hline 193 Sony & Japan & Consumer Products \& Serv. & 48,616 & $\begin{array}{l}1946 \text { Tokyo Telecommunications Engineering } \\
\text { Corporation }\end{array}$ & Tokyo, JP \\
\hline $\begin{array}{l}194 \text { Hon Hai Precision } \\
\text { Instruments }\end{array}$ & Taiwan & Manufacturing & 47,419 & 1970 Hon Hai Precision Industry Co & Taipei, TW \\
\hline 195 Wellpoint & US & Health and Life Sciences & 47,369 & 1944 Blue Cross of Indiana & Indianapolis IN \\
\hline 196 Las Vegas Sands & US & Consumer Products \& Serv. & 47,346 & 1952 Sands Hotel & Las Vegas NV \\
\hline 197 Schering-Plough & US & Health and Life Sciences & 47,328 & 1908 Plough & Memphis TN \\
\hline 198 Westpac Banking & Australia & Banking and Finance & 47,039 & 1817 Bank of New South Wales & Sydney, AU \\
\hline 199 Walgreen & US & Consumer Products \& Serv. & 46,940 & 1901 Walgreens Drugstores & Deerfield IL \\
\hline 200 Monsanto & US & Manufacturing & 46,768 & 1901 Monsanto & St Louis MO \\
\hline 201 Encana & Canada & Oil, Gas and Mining & 46,618 & 1958 PanCanadian Energy & Calgary, CA \\
\hline 202 China Cosco & China & Business Services & 46,124 & 1961 China Ocean Shipping Company & Beijing, CN \\
\hline 203 Hennes \& Mauritz & Sweden & Consumer Products \& Serv. & 46,118 & 1947 Hennes & Västeras, SE \\
\hline $\begin{array}{l}204 \text { Matsushita Electric } \\
\text { Industrial }\end{array}$ & Japan & Consumer Products \& Serv. & 45,962 & 1918 Matsushita Electric Industrial Co & Osaka, JP \\
\hline 205 Imperial Oil & Canada & Oil, Gas and Mining & 45,907 & 1880 Imperial Oil & London, CA \\
\hline 206 Standard Chartered & UK & Banking and Finance & 45,749 & $\begin{array}{l}1852 \text { The Chartered Bank of India, Australia and } \\
\text { China }\end{array}$ & Calcutta, IN \\
\hline 207 Hutchison Whampoa & Hong Kong & Manufacturing & 45,632 & 1863 Hong Kong and Whampoa Dock & Hong Kong, HK \\
\hline $\begin{array}{l}208 \text { Du Pont E I De } \\
\text { Nemours }\end{array}$ & US & Manufacturing & 45,621 & 1802 E.I. du Pont de Nemours & Brandywine Creek DE \\
\hline 209 Nissan Motor & Japan & Manufacturing & 45,241 & 1911 Kwaishinsha Motorcar Works & Tokyo, JP \\
\hline 210 Nordea Bank & Sweden & Banking and Finance & 45,087 & 1820 Sparekassen for Kjøbenhavn og Omegn & Copenhagen, DK \\
\hline 211 Ambev & Brazil & Consumer Products \& Serv. & 45,063 & 1888 Companhia Cervejaria Brahma & Brazil \\
\hline 212 Lockheed Martin & US & Manufacturing & 44,845 & 1912 Loughead Aircraft Manufacturing Company & Santa Barbara CA \\
\hline 213 Bharti Airtel & India & Telecoms and Media & 44,824 & 1985 Bharti Airtel & New Delhi, IN \\
\hline 214 Prudential Financial & US & Insurance & 44,789 & 1875 Prudential Friendly Society & Newark NJ \\
\hline 215 Honeywell International & US & Manufacturing & 44,507 & 1906 Honeywell Heating Specialty Co & Wabash IN \\
\hline 216 Mitsui & Japan & Business Services & 43,924 & 1673 Echigo-Ya & Tokyo, JP \\
\hline 217 Suncor Energy & Canada & Oil, Gas and Mining & 43,864 & 1917 Sun Company of Canada & Montreal, CA \\
\hline 218 EMC & US & Manufacturing & 43,624 & 1979 EMC & Hopkinton MA \\
\hline $\begin{array}{l}219 \text { Zurich Financial } \\
\text { Services }\end{array}$ & Switzerland & Insurance & 43,502 & 1872 Zurich Insurance Company & Zurich, $\mathrm{CH}$ \\
\hline 220 Repsol YPF & Spain & Oil, Gas and Mining & 43,494 & 1922 Yacimientos Petroliferos Fiscales & Buenos Aires, AR \\
\hline 221 JFE Holdings & Japan & Manufacturing & 43,443 & 1896 Kawasaki Group & Tokyo, JP \\
\hline 222 Alcon & Switzerland & Health and Life Sciences & 43,346 & 1947 Alcon & Fort Worth TX \\
\hline 223 Singapore Telecom & Singapore & Telecoms and Media & 43,104 & 1879 Singapore telephone service & Singapore, SG \\
\hline 224 Sabmiller & UK & Consumer Products \& Serv. & 42,663 & 1855 Miller Brewing Company & Milwaukee WI \\
\hline 225 Motorola & US & Manufacturing & 42,500 & 1928 Galvin Manufacturing Corporation & Schaumburg IL \\
\hline 226 Munich Re & Germany & Insurance & 42,462 & 1880 Münchener Rückversicherungs-Gesellschaft & Munich, DE \\
\hline 227 Emerson Electric & US & Manufacturing & 42,152 & 1890 Emerson Electric Manufacturing Co & St Louis MO \\
\hline $\begin{array}{l}228 \text { Sun Hung Kai } \\
\text { Properties }\end{array}$ & Hong Kong & Banking and Finance & 42,019 & 1969 Sun Hung Kai Properties Ltd & Hong Kong, HK \\
\hline 229 Inditex & Spain & Consumer Products \& Serv. & 41,895 & 1975 Zara & A Coruna, ES \\
\hline 230 Reckitt Benckiser & UK & Consumer Products \& Serv. & 41,748 & 1814 Colman's flour \& mustard mill & Norwich, UK \\
\hline 231 Banco Brasil & Brazil & Banking and Finance & 41,567 & 1808 Banco do Brasil & Rio de Janeiro, BR \\
\hline $232 \mathrm{BMW}$ & Germany & Manufacturing & 41,562 & 1913 BMW & Munich, DE \\
\hline 233 National Grid & UK & Energy Services and Utilities & 41,459 & $\begin{array}{l}1880 \text { [Central Electricity Generating Board created } \\
1957 \text { from existing assets] }\end{array}$ & London, UK \\
\hline 234 Lowe's Companies & US & Consumer Products \& Serv. & 41,430 & 1946 Lowe's Home Improvement Warehouse & North Wilkesboro NC \\
\hline 235 Renault & France & Manufacturing & 41,179 & 1899 Société Renault Frères & Boulogne, FR \\
\hline $\begin{array}{l}236 \text { Canadian Natural } \\
\text { Resources }\end{array}$ & Canada & Oil, Gas and Mining & 41,019 & 1989 Canadian Natural Resources & Calgary, CA \\
\hline 237 Freddie Mac & US & Banking and Finance & 40,948 & 1970 Federal Home Loan Mortgage Corporation & McLean VA \\
\hline 238 Dow Chemicals & US & Manufacturing & 40,910 & 1897 Dow Chemical & Midland MI \\
\hline 239 Teliasonera & Sweden & Telecoms and Media & 40,434 & 1853 Kungl. Telegrafverket & Stockholm, SE \\
\hline 240 Danone & France & Consumer Products \& Serv. & 40,261 & 1919 Danone & Barcelona, ES \\
\hline
\end{tabular}




\begin{tabular}{|c|c|c|c|c|c|}
\hline Rank Company & Country & Sector & $\begin{array}{r}\text { Market Cap } \\
30 / 09 / 2007 \\
\text { \$m }\end{array}$ & $\begin{array}{l}\text { Birth Name at creation } \\
\text { Date }\end{array}$ & Place of creation \\
\hline 241 Carnival & US & Consumer Products \& Serv. & 40,243 & 1972 Carnival Cruise Lines & Miami FL \\
\hline 242 Veolia Environnement & France & Energy Services and Utilities & 40,149 & 1853 Compagnie Générale des Eaux & Paris, FR \\
\hline $\begin{array}{l}243 \text { Freeport-Mcmoran } \\
\text { Copper \& Gold }\end{array}$ & US & Manufacturing & 40,040 & 1834 Phelps Dodge & New York NY \\
\hline 244 NTPC & India & Energy Services and Utilities & 40,030 & 1975 National Thermal Power Corp & New Delhi, IN \\
\hline 245 Telstra & Australia & Telecoms and Media & 39,814 & 1901 Postmaster-General's Department & Canberra, AU \\
\hline 246 Mitsubishi Estate & Japan & Banking and Finance & 39,547 & 1937 Mitsubishi Estate & Tokyo, JP \\
\hline 247 Aviva & UK & Insurance & 38,930 & 1797 Norwich Union & Norwich, UK \\
\hline 248 Saint Gobain & France & Manufacturing & 38,923 & 1665 Compagnie de Saint-Gobain & Saint Gobain, FR \\
\hline 249 Corning & US & Manufacturing & 38,914 & 1851 Corning Glass & New York NY \\
\hline 250 Marathon Oil & US & Oil, Gas and Mining & 38,836 & 1887 The Ohio Oil Company & Canton $\mathrm{OH}$ \\
\hline 251 Amazon.Com & US & Consumer Products \& Serv. & 38,508 & 1994 Cadabra.com & Seattle WA \\
\hline 252 Cheung Kong & Hong Kong & Banking and Finance & 38,222 & 1950 Cheung Kong Industries & Hong Kong, HK \\
\hline 253 Gilead Sciences & US & Health and Life Sciences & 37,860 & 1987 Oligogen & Foster City CA \\
\hline 254 Prudential & UK & Insurance & 37,808 & $\begin{array}{l}1848 \text { The Prudential Mutual Assurance Investment } \\
\text { and Loan Association }\end{array}$ & London, UK \\
\hline 255 Vinci & France & Manufacturing & 37,621 & 1899 Société générale d'entreprises & Paris, FR \\
\hline 256 Fiat & Italy & Manufacturing & 37,604 & 1899 Fabbrica Italiana Automobili Torino & Turin, IT \\
\hline 257 Anheuser-Busch & US & Consumer Products \& Serv. & 37,471 & 1860 Anheuser-Busch & Saint Louis MO \\
\hline 258 Alcan & Canada & Manufacturing & 37,218 & 1902 Canadian Unit of Alcoa & Montreal, CA \\
\hline 259 Valero Energy & US & Oil, Gas and Mining & 37,206 & 1951 Coastal & Corpus Christi TX \\
\hline 260 Devon Energy & US & Oil, Gas and Mining & 37,096 & 1971 Devon Energy & Oklahoma City OK \\
\hline 261 Westfield Group & Australia & Banking and Finance & 37,056 & 1959 Westfield Place & Sydney, AU \\
\hline 262 Volvo & Sweden & Manufacturing & 36,906 & 1927 Volvo & Gothenburg, SE \\
\hline 263 Southern Copper & US & Manufacturing & 36,464 & 1952 SPCC & Wilmington, $\mathrm{DE}$ \\
\hline 264 Colgate-Palmolive & US & Consumer Products \& Serv. & 36,369 & 1806 William Colgate \& Co & New York NY \\
\hline 265 CEZ & Czech Republic & Energy Services and Utilities & 36,340 & 1885 [CEZ created in 1992 from existing assets] & Prague, $\mathrm{CZ}$ \\
\hline 266 Baxter International & US & Health and Life Sciences & 36,285 & 1931 Baxter & Deerfield IL \\
\hline 267 Yahoo & US & Telecoms and Media & 35,957 & 1995 Yahoo! & Santa Clara CA \\
\hline 268 Teva Pharmaceutical & Israel & Health and Life Sciences & 35,746 & 1901 Salomon, Levin, and Elstein Ltd & Jerusalem, IL \\
\hline 269 Anglo Platinum & South Africa & Oil, Gas and Mining & 35,695 & 1955 Amplats & Johannesbourg, ZA \\
\hline 270 STC & Saudi Arabia & Telecoms and Media & 35,414 & $\begin{array}{l}1935 \text { [Saudi Telecom Company created in } 1998 \\
\text { from existing assets] }\end{array}$ & Ryad, SA \\
\hline 271 Husky Energy & Canada & Oil, Gas and Mining & 35,404 & 1938 Husky Refining Company & Calgary, CA \\
\hline 272 Bae Systems & UK & Manufacturing & 35,292 & 1828 Vickers & Sheffield, UK \\
\hline 273 Dexia & Belgium & Banking and Finance & 35,204 & 1860 Crédit Communal de Belgique & Brussels, BE \\
\hline $\begin{array}{l}274 \text { Hyundai Heavy } \\
\text { Industries }\end{array}$ & South Korea & Manufacturing & 35,129 & 1947 Hyundai & Seoul, KR \\
\hline 275 Barrick Gold & Canada & Oil, Gas and Mining & 34,796 & 1983 Barrick & Toronto, CA \\
\hline 276 Deutsche Post & Germany & Business Services & 34,735 & 1597 Kaiserliche Reichspost & Brussels, BE \\
\hline 277 Alcoa & US & Manufacturing & 34,583 & 1894 Pittsburgh Aluminium Company & Pittsburgh PA \\
\hline 278 Richemont & Switzerland & Consumer Products \& Serv. & 34,474 & 1847 Cartier & Paris, FR \\
\hline 279 General Dynamics & US & Manufacturing & 34,270 & 1899 Electric Boat Company & Groton CT \\
\hline 280 Halliburton & US & Manufacturing & 34,182 & 1919 Halliburton & Dallas TX \\
\hline 281 Tokyo Electric Power & Japan & Energy Services and Utilities & 34,111 & $\begin{array}{l}1890 \text { [Tokyo Electric Power Company created in } \\
1951 \text { from existing assets] }\end{array}$ & Tokyo, JP \\
\hline 282 Novo Nordisk & Denmark & Health and Life Sciences & 34,096 & 1923 Nordisk Insulinlaboratorium & Bagsværd, DK \\
\hline 283 Hang Seng Bank & Hong Kong & Banking and Finance & 33,986 & 1935 Hang Seng & Hong Kong, HK \\
\hline 284 Komatsu & Japan & Manufacturing & 33,519 & 1917 Komatsu Iron Works & Komatsu, JP \\
\hline $\begin{array}{l}285 \text { Canadian Imperial Bank } \\
\text { of Commerce }\end{array}$ & Canada & Banking and Finance & 33,470 & 1867 Canadian Bank of Commerce & Toronto, CA \\
\hline 286 Telenor & Norway & Telecoms and Media & 33,467 & 1855 Telegrafverket & Oslo, NO \\
\hline 287 Allstate & US & Insurance & 33,456 & 1931 Allstate & Northbrooke IL \\
\hline 288 Potash Sask & Canada & Manufacturing & 33,395 & 1955 Start of potash production & Saskatoon, CA \\
\hline $289 \mathrm{KPN}$ & Netherlands & Telecoms and Media & 33,379 & $\begin{array}{l}1880 \text { [Staatsbedrijf der P\&T created in } 1915 \text { from } \\
\text { existing assets] }\end{array}$ & Den Haag, NL \\
\hline 290 Denso & Japan & Manufacturing & 33,283 & 1949 Nippondenso & Kariya, JP \\
\hline $291 \mathrm{KDDI}$ & Japan & Telecoms and Media & 33,224 & 1953 Kokusai Denshin Denwa Co & Tokyo, JP \\
\hline 292 Millea & Japan & Insurance & 33,120 & 1876 Tokio Marine \& Nichido Fire Insurance Co & Tokyo, JP \\
\hline 293 The Travelers Cos & US & Insurance & 33,049 & 1853 St. Paul Companies & St Paul MN \\
\hline 294 Deere & US & Manufacturing & 32,931 & 1842 Andrus Plough Manufactory & Rock River IL \\
\hline 295 Illinois Tool Works & US & Manufacturing & 32,923 & 1912 Illinois Tool Works & Glenview IL \\
\hline 296 Nomura & Japan & Banking and Finance & 32,921 & 1925 Nomura & Osaka, JP \\
\hline 297 Swiss RE & Switzerland & Insurance & 32,877 & 1863 Swiss Re & Zurich, $\mathrm{CH}$ \\
\hline 298 Transocean & US & Manufacturing & 32,807 & 1926 Danciger Oil \& Refining Company & ??? LA \\
\hline 299 Lehman Brothers & US & Banking and Finance & 32,765 & 1850 H. Lehman & Montgomery AL \\
\hline 300 Great West Lifeco & Canada & Insurance & 32,764 & 1891 Great-West Life & Winnipeg, CA \\
\hline
\end{tabular}




\begin{tabular}{|c|c|c|c|c|c|}
\hline Rank Company & Country & Sector & $\begin{array}{r}\text { Market Cap } \\
30 / 09 / 2007 \\
\$ \mathrm{~m}\end{array}$ & $\begin{array}{l}\text { Birth Name at creation } \\
\text { Date }\end{array}$ & Place of creation \\
\hline $\begin{array}{l}301 \text { Hong Kong Exchanges } \\
\text { \& Clearing }\end{array}$ & Hong Kong & Banking and Finance & 32,702 & 1891 Hong Kong Stock Exchange & Hong Kong, HK \\
\hline 302 Thyssenkrupp & Germany & Manufacturing & 32,677 & 1811 Krupp Steel Foundry & Essen, DE \\
\hline 303 Fortum & Finland & Energy Services and Utilities & 32,658 & 1921 Imatran Voima Oy & Helsinki, FI \\
\hline 304 DLF & India & Banking and Finance & 32,642 & 1946 Delhi Land and Finance & New Delhi, IN \\
\hline $\begin{array}{l}305 \text { Bank of Montreal } \\
\text { Quebec }\end{array}$ & Canada & Banking and Finance & 32,636 & 1817 Bank of Montreal & Montreal, CA \\
\hline 306 Fedex & US & Business Services & 32,396 & 1973 Federal Express & Little Rock AR \\
\hline 307 Air Liquide & France & Manufacturing & 32,325 & 1902 Air Liquide & Paris, FR \\
\hline $308 \mathrm{BCE}$ & Canada & Telecoms and Media & 32,287 & 1880 Bell Telephone Company of Canada Ltd. & Montreal, CA \\
\hline 309 CME Group & US & Banking and Finance & 32,166 & 1898 Chicago Butter and Egg Board & Chicago IL \\
\hline 310 Heineken & Netherlands & Consumer Products \& Serv. & 32,068 & 1864 De Hooiberg & Amsterdam, NL \\
\hline 311 Woolworths & Australia & Consumer Products \& Serv. & 31,842 & 1924 Woolworths Stupendous Bargain Basement & Sydney, AU \\
\hline 312 TXU & US & Energy Services and Utilities & 31,575 & 1882 Dallas Power \& Light & Dallas TX \\
\hline 313 East Japan Railway & Japan & Consumer Products \& Serv. & 31,509 & $\begin{array}{l}1870 \text { [East Japan Railway created in } 1972 \text { from } \\
\text { existing assets] }\end{array}$ & Tokyo, JP \\
\hline 314 Franklin Resources & US & Banking and Finance & 31,358 & 1947 Franklin Distributors, Inc & New York NY \\
\hline 315 Walmex & Mexico & Consumer Products \& Serv. & 31,210 & 1958 Aurrera & Mexico, MX \\
\hline 316 Tenaris & Argentina & Manufacturing & 31,137 & 1909 Dalmine & Milan, IT \\
\hline 317 Al Rajhi Banking & Saudi Arabia & Banking and Finance & 31,121 & $\begin{array}{l}1955 \text { [Various banking outfits merged into Al Rajhi in } \\
\text { 1978] }\end{array}$ & Riyad, SA \\
\hline 318 Aegon & Netherlands & Insurance & 30,998 & 1844 Algemeene Friesche & Amsterdam, NL \\
\hline 319 Air China & China & Consumer Products \& Serv. & 30,952 & $\begin{array}{l}1925 \text { [Civil Aviation Administration of China created } \\
1949 \text { from existing assets] }\end{array}$ & Beijing, CN \\
\hline 320 Imperial Tobacco & UK & Consumer Products \& Serv. & 30,932 & 1786 Wills, Watkins \& Co & Bristol, UK \\
\hline 321 VTB Bank & Russia & Banking and Finance & 30,931 & 1990 VTB & Moscow, RU \\
\hline 322 Schneider Electric & France & Manufacturing & 30,891 & 1836 Schneider & Le Creusot, FR \\
\hline 323 Washington Mutual & US & Banking and Finance & 30,740 & $\begin{array}{l}1889 \text { Washington National Building Loan and } \\
\text { Investment Association }\end{array}$ & Seattle WA \\
\hline 324 Woodside Petroleum & Australia & Oil, Gas and Mining & 30,578 & 1954 Woodside (Lakes Entrance) Oil Co NL & Perth, AU \\
\hline 325 Reed Elsevier & Netherlands/UK & Telecoms and Media & 30,373 & 1880 NV Uitgeversmaatschappij Elsevier & Rotterdam, NL \\
\hline 326 Etisalat & UAE & Telecoms and Media & 30,360 & 1976 Emirtel & Abu Dhabi, AE \\
\hline $\begin{array}{l}327 \text { National Bank of } \\
\text { Greece }\end{array}$ & Greece & Banking and Finance & 30,215 & 1841 National Bank of Greece & Athens, GR \\
\hline 328 Toshiba & Japan & Manufacturing & 30,194 & 1875 Tanaka Engineering Works & Tokyo, JP \\
\hline 329 Union Pacific & US & Business Services & 30,098 & 1862 Union Pacific Railroad & Omaha NE \\
\hline 330 Korea Electric Power & South Korea & Energy Services and Utilities & 30,075 & $\begin{array}{l}1910 \text { [Korea Electric Power created in } 1961 \text { from } \\
\text { existing assets] }\end{array}$ & Seoul, KR \\
\hline $\begin{array}{l}331 \text { Reliance } \\
\text { Communications }\end{array}$ & India & Telecoms and Media & 30,050 & 1999 Reliance Infocomm & Mumbai, IN \\
\hline $\begin{array}{l}332 \text { Rogers } \\
\text { Communications }\end{array}$ & Canada & Telecoms and Media & 29,963 & 1959 Aldred-Rogers Broadcasting Ltd & Toronto, CA \\
\hline 333 Kimberly-Clark & US & Consumer Products \& Serv. & 29,904 & 1872 Kimberly, Clark and Co & Neenah WI \\
\hline 334 Apache & us & Oil, Gas and Mining & 29,901 & 1950 Apache Oil Corporation & Minneapolis MN \\
\hline 335 Sun Life Financial & Canada & Insurance & 29,839 & 1865 Sun Mutual Life Insurance Company & Montreal, CA \\
\hline 336 Shin-Etsu Chemical & Japan & Manufacturing & 29,830 & 1926 Shin-Etsu Nitrogen Fertilizer Co., Ltd. & Nagano, JP \\
\hline 337 Bouygues & France & Manufacturing & 29,634 & 1952 E.F.B. & Paris, FR \\
\hline 338 Time Warner Cable & US & Telecoms and Media & 29,583 & $\begin{array}{l}1980 \text { [Time Warner Cable created in } 1989 \text { from } \\
\text { existing assets] }\end{array}$ & New York NY \\
\hline 339 Power Financial & Canada & Insurance & 29,438 & 1847 Canada Life Financial Corporation & Hamilton, CA \\
\hline 340 Dominion Resources & US & Energy Services and Utilities & 29,413 & 1795 Upper Appomattox Company & Richmond VA \\
\hline $\begin{array}{l}341 \text { Hartford Financial } \\
\text { Services }\end{array}$ & US & Insurance & 29,401 & 1810 Hartford Fire Insurance Company & Hartford CT \\
\hline 342 Metro & Germany & Consumer Products \& Serv. & 29,383 & 1964 Metro Cash \& Carry & Düsseldorf, DE \\
\hline $343 \mathrm{ICICI}$ Bank & India & Banking and Finance & 29,201 & $\begin{array}{l}1955 \text { Industrial Credit and Investment Corporation of } \\
\text { India }\end{array}$ & f Mumbai, IN \\
\hline 344 Holcim & Switzerland & Manufacturing & 29,017 & 1912 Holderbank-Gruppe & Holderbank, $\mathrm{CH}$ \\
\hline 345 Baker Hughes & US & Manufacturing & 28,878 & 1909 Hughes Tool Company & Houston TX? \\
\hline 346 The DirecTV Group & us & Telecoms and Media & 28,860 & 1981 US Satellite Broadcasting & El Secundo CA \\
\hline $\begin{array}{l}347 \text { Canadian National } \\
\text { Railways }\end{array}$ & Canada & Business Services & 28,703 & 1871 Prince Edward Island Railway & Charlottetown, CA \\
\hline $\begin{array}{l}348 \text { Burlington Northern } \\
\text { Santa Fe }\end{array}$ & US & Business Services & 28,687 & 1849 Chicago, Burlington and Quincy Railroad & Chicago IL \\
\hline 349 Itausa & Brazil & & 28,683 & 1944 Banco Itau & \\
\hline 350 Applied Materials & US & Manufacturing & 28,527 & 1967 Applied Materials & Santa Clara CA \\
\hline 351 Centrica & UK & Energy Services and Utilities & 28,515 & 1812 Gas Light and Coke Company & London, UK \\
\hline 352 Danske Bank & Denmark & Banking and Finance & 28,298 & $\begin{array}{l}1871 \text { Danske Landmandsbank, Hypothek- og } \\
\text { Vexelbank i Kjøbenhavn }\end{array}$ & Copenhagen, DK \\
\hline 353 Liberty & US & Telecoms and Media & 28,253 & 1956 Memphis Cable System & Memphis TN \\
\hline 354 MTN Group & South Africa & Telecoms and Media & 28,215 & 1994 M-Cell & Johannesburg, ZA \\
\hline 355 Stryker & US & Health and Life Sciences & 28,187 & 1946 Orthopedic Frame Company & Kalamazoo Ml \\
\hline 356 China Unicom & Hong Kong & Telecoms and Media & 28,185 & 1994 China United Telecommunications Corporation & Beijing, CN \\
\hline 357 Alstom & France & Manufacturing & 28,107 & 1839 Atelier de construction Koechlin & Mulhouse, FR \\
\hline
\end{tabular}




\begin{tabular}{|c|c|c|c|c|c|}
\hline Rank Company & Country & Sector & $\begin{array}{r}\text { Market Cap } \\
30 / 09 / 2007 \\
\$ \mathrm{~m}\end{array}$ & $\begin{array}{l}\text { Birth Name at creation } \\
\text { Date }\end{array}$ & Place of creation \\
\hline 361 Raytheon & US & Manufacturing & 27,911 & 1922 American Appliance Company & Cambridge MA \\
\hline 362 Aflac & US & Insurance & 27,872 & 1955 American Family Life Insurance Company & Columbus GA \\
\hline 363 Country Garden & Hong Kong & Banking and Finance & 27,840 & 1997 Country Garden & Foshan, CN \\
\hline 364 Formosa Petrochemical & Taiwan & Oil, Gas and Mining & 27,772 & 1954 Formosa Plastics & Taipei, TW \\
\hline 365 Aetna & US & Health and Life Sciences & 27,754 & 1820 Aetna Insurance Company & Hartford CT \\
\hline 366 Capital One Financial & US & Banking and Finance & 27,747 & 1989 Capital One Financial & McLean VA \\
\hline 367 Angang Steel & China & Manufacturing & 27,635 & $\begin{array}{l}1955 \text { [Angang Steel created in } 1997 \text { from existing } \\
\text { assets] }\end{array}$ & Anshan, CN \\
\hline 368 PTT & Thailand & Oil, Gas and Mining & 27,578 & 1921 Start of oil production & Bangkok, TH \\
\hline 369 Southern & US & Energy Services and Utilities & 27,443 & 1882 Metropolitan Street Railroad Company & Atlanta GA \\
\hline 370 Celgene & US & Health and Life Sciences & 27,293 & 1986 Celgene & Summit NJ \\
\hline 371 Infosys Technologies & India & Business Services & 27,190 & 1981 Infosys Consultants Pvt Ltd & Pune, IN \\
\hline 372 Deutsche Boerse & Germany & Banking and Finance & 27,164 & 1682 Börse & Frankfurt, DE \\
\hline 373 Charles Schwab & US & Banking and Finance & 27,088 & 1963 Investment Indicator & San Francisco CA \\
\hline $\begin{array}{l}374 \text { Datang Intl Power } \\
\text { Generation }\end{array}$ & China & Energy Services and Utilities & 27,073 & $\begin{array}{l}1994 \text { Beijing Datang Power Generation Company } \\
\text { Limited }\end{array}$ & Beijing, CN \\
\hline 375 Natixis & France & Banking and Finance & 27,000 & 1878 Groupe Banques Populaires & Paris, FR \\
\hline 376 Sasol & South Africa & Oil, Gas and Mining & 26,984 & 1950 Suid Afrikaanse Steenkool en Olie & Johannesburg, ZA \\
\hline 377 Northrop Grumman & US & Manufacturing & 26,982 & 1929 Grumman Aircraft Engineering Corporation & Baldwin NY \\
\hline 378 Mitsubishi Electric & Japan & Manufacturing & 26,883 & 1921 Mitsubishi Electric & Tokyo, JP \\
\hline 379 Costco Wholesale & US & Consumer Products \& Serv. & 26,876 & 1983 Costco & Seattle WA \\
\hline 380 Petroleos (Cepsa) & Spain & Oil, Gas and Mining & 26,866 & 1927 Compañía Española de Petróleos S.A. & Madrid, ES \\
\hline 381 Thomson & Canada & Telecoms and Media & 26,849 & 1934 Thomson Newspapers & Toronto, CA \\
\hline 382 Boc Hong Kong & Hong Kong & Banking and Finance & 26,811 & 1917 Bank of China & Hong Kong, HK \\
\hline 383 Praxair & US & Manufacturing & 26,791 & 1907 Praxair & Danbury CT \\
\hline 384 Lafarge & France & Manufacturing & 26,775 & 1833 Lafarge & Le Teil, FR \\
\hline 385 Viacom & US & Telecoms and Media & 26,756 & 1912 Paramount Pictures Corporation & Los Angeles CA \\
\hline 386 State Street & US & Banking and Finance & 26,549 & 1792 State Street Corporation & Boston MA \\
\hline 387 Commerzbank & Germany & Banking and Finance & 26,534 & 1870 Commerzbank & Hamburg, DE \\
\hline $\begin{array}{l}388 \text { Scottish \& Southern } \\
\text { Energy }\end{array}$ & UK & Energy Services and Utilities & 26,499 & $\begin{array}{l}1890 \text { [North of Scotland Hydro-Electric Board } \\
\text { created } 1943 \text { from existing assets] }\end{array}$ & Edinburgh, UK \\
\hline 389 Suntrust Banks & US & Banking and Finance & 26,431 & 1891 Commercial Travelers' Savings Bank & Atlanta GA \\
\hline $\begin{array}{l}390 \text { Tata Consultancy } \\
\text { Services }\end{array}$ & India & Business Services & 25,953 & 1968 Tata Consultancy Services & Mumbai, IN \\
\hline 391 Loews & US & Insurance & 25,876 & $\begin{array}{l}1897 \text { Continental Assurance Company of North } \\
\text { America }\end{array}$ & Detroit MI \\
\hline 392 Garmin & US & Consumer Products \& Serv. & 25,867 & 1989 ProNav & George Town, KY \\
\hline 393 QBE Insurance Group & Australia & Insurance & 25,807 & $\begin{array}{l}1886 \text { The North Queensland Insurance Company } \\
\text { Limited }\end{array}$ & Townsville, AU \\
\hline 394 State Bank of India & India & Banking and Finance & 25,765 & 1806 Bank of Calcutta & Calcutta, IN \\
\hline 395 National Oilwell Varco & US & Manufacturing & 25,750 & 1862 Oilwell Supply & Houston TX \\
\hline 396 Adobe Systems & US & Business Services & 25,691 & 1982 Adobe Systems & San José CA \\
\hline 397 Capitalia & Italy & Banking and Finance & 25,618 & 1605 Banco di Santo Spirito & Rome, IT \\
\hline 398 Danaher & US & Manufacturing & 25,489 & 1969 DMG Inc & Washington DC \\
\hline 399 MGM Mirage & US & Consumer Products \& Serv. & 25,432 & 1946 Golden Nugget Hotel & Las Vegas NV \\
\hline 400 Sandvik & Sweden & Manufacturing & 25,352 & 1862 Sandvik & Sandviken, SE \\
\hline 401 Gas Natural & Spain & Energy Services and Utilities & 25,218 & 1843 Sociedad Catalana para el Alumbrado por Gas & Barcelona, ES \\
\hline $\begin{array}{l}402 \text { Huaneng Power } \\
\text { International }\end{array}$ & China & Energy Services and Utilities & 25,111 & 1994 Huaneng Power & Beijing, CN \\
\hline 403 Anadarko Petroleum & US & Oil, Gas and Mining & 25,033 & 1959 Anadarko & Houston TX \\
\hline $\begin{array}{l}404 \text { Bharat Heavy } \\
\text { Electricals }\end{array}$ & India & Manufacturing & 24,972 & 1962 Bharat Heavy Electricals & New Delhi, IN \\
\hline 405 Eads & France & Manufacturing & 24,953 & $\begin{array}{l}1911 \text { Société provisoire des Aéroplanes } \\
\text { Desperdussion }\end{array}$ & Paris, FR \\
\hline $\begin{array}{l}406 \text { Shinhan Financial } \\
\text { Group }\end{array}$ & South Korea & Banking and Finance & 24,933 & 1897 Chohung Bank & Seoul, KR \\
\hline 407 Seven \& I & Japan & Consumer Products \& Serv. & 24,864 & 1920 Tosho Yoshikawa Store & Tokyo, JP \\
\hline 408 Astellas Pharma & Japan & Health and Life Sciences & 24,862 & 1894 Fujisawa Shoten & Osaka, JP \\
\hline $\begin{array}{l}409 \text { British Sky } \\
\text { Broadcasting }\end{array}$ & UK & Telecoms and Media & 24,820 & 1982 Sky Channel & London, UK \\
\hline 410 FPL Group & US & Energy Services and Utilities & 24,768 & 1895 [Incorporated in 1925 as Florida Light \& Power] & Juno beach FL \\
\hline $\begin{array}{l}411 \text { Thermo Fisher } \\
\text { Scientific }\end{array}$ & US & Health and Life Sciences & 24,622 & 1902 Fisher Scientific & Hampton $\mathrm{NH}$ \\
\hline 412 Medco Health Solutions & US & Health and Life Sciences & 24,476 & 1965 National Pharmacies Inc. & Parsippany NJ \\
\hline 413 Mitsui Fudosan & Japan & Banking and Finance & 24,447 & 1914 Mitsui Real Estate & Tokyo, JP \\
\hline $\begin{array}{l}414 \text { Automatic Data } \\
\text { Processing }\end{array}$ & US & Business Services & 24,392 & 1949 Automatic Data Processing & Roseland NJ \\
\hline 415 Fanuc & Japan & Manufacturing & 24,385 & 1956 FANUC & Oshino-Mura, JP \\
\hline 416 Cadbury Schweppes & & Consumer Products \& Serv. & 24,306 & 1790 Schweppes & London, UK \\
\hline $\begin{array}{l}417 \text { Telekomunikasi } \\
\text { Indonesia }\end{array}$ & Indonesia & Telecoms and Media & 24,249 & $\begin{array}{l}1905 \text { [Perumtel created in } 1991 \text { from existing } \\
\text { assets] }\end{array}$ & Banndung, ID \\
\hline
\end{tabular}




\begin{tabular}{|c|c|c|c|c|c|}
\hline Rank Company & Country & Sector & $\begin{array}{r}\text { Market Cap } \\
30 / 09 / 2007 \\
\$ \mathrm{~m}\end{array}$ & $\begin{array}{l}\text { Birth Name at creation } \\
\text { Date }\end{array}$ & Place of creation \\
\hline 421 Erste Bank & Austria & Banking and Finance & 23,967 & $\begin{array}{l}1819 \text { Verein der Ersten österreichischen Spar- } \\
\text { Casse }\end{array}$ & Vienna, AT \\
\hline 422 Alltel & US & Telecoms and Media & 23,962 & 1943 Allied Telephone Co & Little Rock AR \\
\hline 423 XTO Energy & US & Oil, Gas and Mining & 23,859 & 1986 XTO Energy & Fort Worth TX \\
\hline 424 Pernod-Ricard & France & Consumer Products \& Serv. & 23,855 & 1797 Pernod Dubiet absinthe distillery & Couvet, $\mathrm{CH}$ \\
\hline 425 Accenture & US & Business Services & 23,799 & 1953 Arthur Andersen & Chicago IL \\
\hline 426 Central Japan Railway & Japan & Consumer Products \& Serv. & 23,760 & $\begin{array}{l}1870 \text { [Central Japan Railway created in } 1972 \text { from } \\
\text { existing assets] }\end{array}$ & Tokyo, JP \\
\hline 427 Fujifilm & Japan & Consumer Products \& Serv. & 23,759 & 1934 Fujifilm & Tokyo, JP \\
\hline 428 Alcatel Lucent & France & Manufacturing & 23,650 & 1898 Compagnie Générale d'Electricité & Paris, FR \\
\hline 429 Mosaic & US & Manufacturing & 23,620 & 1865 Cargill family business & Wayzata MN \\
\hline 430 Duke Energy & US & Energy Services and Utilities & 23,554 & 1900 Catawba Power Company & Charlotte NC \\
\hline 431 Akzo Nobel & Netherlands & Manufacturing & 23,522 & 1792 Sikken Lakkens & Groningen, NL \\
\hline 432 Cemex & Mexico & Manufacturing & 23,514 & 1906 Cementos Hidalgo & Hidalgo, MX \\
\hline 433 Johnson Controls & US & Manufacturing & 23,364 & 1885 Johnson Controls & Milwaukee WI \\
\hline 434 Christian Dior & France & Consumer Products \& Serv. & 23,193 & 1947 Christian Dior & Paris, FR \\
\hline 435 PNC Financial Services & US & Banking and Finance & 23,140 & 1852 Pittsburgh Trust and Savings Company & Pittsburgh PA \\
\hline 436 Mobile Telesystems & Russia & Telecoms and Media & 23,023 & 1882 Moscow City Telephone Network & Moscow, RU \\
\hline 437 Yahoo Japan & Japan & Telecoms and Media & 22,875 & 1996 Yahoo Japan & Tokyo, JP \\
\hline 438 Cardinal Health & US & Consumer Products \& Serv. & 22,794 & 1971 Cardinal Foods & Dublin, IE \\
\hline 439 Akbank & Turkey & Banking and Finance & 22,785 & 1948 Akbank & Adana, TR \\
\hline 440 United Overseas Bank & Singapore & Banking and Finance & 22,685 & 1935 United Overseas Bank Limited & Singapore, SG \\
\hline $\begin{array}{l}441 \text { Renewable Energy } \\
\text { Corporation }\end{array}$ & Norway & Manufacturing & 22,648 & 1994 Scanwafer AS & Oslo, NO \\
\hline $\begin{array}{l}442 \text { Weatherford } \\
\text { International }\end{array}$ & US & Manufacturing & 22,639 & 1987 Weatherford International & Houston TX \\
\hline 443 Nike & us & Consumer Products \& Serv. & 22,558 & 1964 Blue Ribbon Sports & Beaverton OR \\
\hline $\begin{array}{l}444 \text { Raiffeisen International } \\
\text { Bank }\end{array}$ & Austria & Banking and Finance & 22,546 & 1927 Raiffeisen Zentralbank Österreich & Vienna, AT \\
\hline 445 Hitachi & Japan & Manufacturing & 22,402 & 1910 Hitachi Works & Tokyo, JP \\
\hline $\begin{array}{l}446 \text { Brookfield Asset } \\
\text { Management }\end{array}$ & Canada & Banking and Finance & 22,401 & 1897 São Paulo Railway, Light and Power Company & Sao Paolo, BR \\
\hline $\begin{array}{l}447 \text { Public.Service } \\
\text { Enterprise }\end{array}$ & US & Energy Services and Utilities & 22,374 & $\begin{array}{l}1890 \text { [Public Service Corporation created in } 1903 \\
\text { from existing assets] }\end{array}$ & Jersey City NJ \\
\hline 448 Simon Property Group & us & Banking and Finance & 22,339 & 1960 Melvin Simon \& Associates & Indianapolis IN \\
\hline 449 BB \& $T$ & US & Banking and Finance & 22,270 & 1872 Branch and Hadley & Wilson NC \\
\hline 450 Kellogg & US & Consumer Products \& Serv. & 22,161 & 1906 Battle Creek Toasted Corn Flake Company & Battle Creek MI \\
\hline 451 Man Group & UK & Banking and Finance & 22,109 & 1783 James Man Sugar Brokerage & London, UK \\
\hline 452 DBS Group & Singapore & Banking and Finance & 22,075 & 1968 Development Bank of Singapore & Singapore, SG \\
\hline 453 Daiichi Sankyo & Japan & Health and Life Sciences & 22,048 & 1899 Sankyo Shoten & Tokyo, JP \\
\hline $\begin{array}{l}454 \text { Mitsubishi Heavy } \\
\text { Industries }\end{array}$ & Japan & Manufacturing & 22,029 & 1870 Nagasaki Shipyard \& Machinery Works & Nagasaki, JP \\
\hline 455 Tyco International & us & Manufacturing & 21,976 & $1887 \mathrm{ADT}$ & Boca Raton FL \\
\hline 456 Kansai Electric Power & Japan & Energy Services and Utilities & 21,972 & $\begin{array}{l}1895 \text { [Kansai Electric Power Co created in } 1951 \\
\text { from existing assets] }\end{array}$ & Osaka, JP \\
\hline 457 Impala Platinum & South Africa & Oil, Gas and Mining & 21,955 & 1967 Mining operation & Rustenburg, ZA \\
\hline 458 Cathay Financial & Taiwan & Banking and Finance & 21,945 & 1962 Cathay Life Insurance & Taipei, TW \\
\hline 459 Best Buy & US & Consumer Products \& Serv. & 21,809 & 1966 Sound of Music & Saint Paul MN \\
\hline 460 Sysco & US & Consumer Products \& Serv. & 21,709 & 1969 Systems and Services Company & Houston TX \\
\hline 461 Syngenta & Switzerland & Manufacturing & 21,650 & 1939 Sandoz Agricultural Chemicals & Basel, $\mathrm{CH}$ \\
\hline $462 \mathrm{CRH}$ & Ireland & Manufacturing & 21,601 & 1936 Ireland Cement Ltd & Dublin, IE \\
\hline 463 Goldcorp & Canada & Oil, Gas and Mining & 21,553 & 1954 Goldcorp & Vancouver, CA \\
\hline 464 Vimpelcom & Russia & Telecoms and Media & 21,538 & 1992 Vimpelcom & Moscow, RU \\
\hline 465 Swisscom & Switzerland & Telecoms and Media & 21,497 & 1852 St Gallen - Zurich Telegraph Service & Zurich, $\mathrm{CH}$ \\
\hline 466 SEB & Sweden & Banking and Finance & 21,471 & 1856 Stockholms Enskilda Bank & Stockholm, SE \\
\hline 467 Steel Authority of India & India & Manufacturing & 21,462 & 1954 Steel Authority of India & New Delhi, IN \\
\hline 468 Henkel & Germany & Consumer Products \& Serv. & 21,415 & 1876 Henkel \& Cie & Aachen, DE \\
\hline 469 Marks \& Spencer & UK & Consumer Products \& Serv. & 21,339 & 1884 Pudi Bazaar & Birmingham, UK \\
\hline 470 Energias de Portugal & Portugal & Energy Services and Utilities & 21,321 & $\begin{array}{l}1895 \text { [Electricidade de Portugal created in } 1976 \text { from } \\
\text { existing assets] }\end{array}$ & Lisbon, PT \\
\hline 471 Archer-Daniels-Midland & US & Consumer Products \& Serv. & 21,290 & 1902 Archer-Daniels Linseed Company & Decatur IL \\
\hline 472 Allied Irish Banks & Ireland & Banking and Finance & 21,288 & 1825 Provincial Bank & Dublin, IE \\
\hline $473 \mathrm{CBS}$ & US & Telecoms and Media & 21,279 & 1927 United Independent Broadcasters & New York NY \\
\hline 474 Severstal & Russia & Manufacturing & 21,212 & 1940 Cheropovets Mill & Cherepovets, RU \\
\hline 475 Paccar & US & Manufacturing & 21,192 & 1905 Seattle Car Manufacturing Company & Seattle WA \\
\hline 476 Entergy & US & Energy Services and Utilities & 21,190 & 1914 Arkansas Power \& Light & Malvern AR \\
\hline 477 Hess & US & Oil, Gas and Mining & 21,156 & 1919 Amerada Corporation & New York NY \\
\hline 478 Atlas Copco & Sweden & Manufacturing & 21,127 & 1873 AB Atlas & Stockholm, SE \\
\hline $\begin{array}{l}479 \text { Air Products \& } \\
\text { Chemicals }\end{array}$ & US & Manufacturing & 21,126 & 1940 Air Products & Detroit MI \\
\hline 480 Accor & France & Consumer Products \& Serv. & 21,104 & $\begin{array}{l}1967 \text { Société d'Investissement et d'Exploitation } \\
\text { Hoteliers }\end{array}$ & Evry, FR \\
\hline
\end{tabular}




\begin{tabular}{|c|c|c|c|c|c|}
\hline Rank Company & Country & Sector & $\begin{array}{r}\text { Market Cap } \\
30 / 09 / 2007 \\
\$ \mathrm{~m}\end{array}$ & $\begin{array}{l}\text { Birth Name at creation } \\
\text { Date }\end{array}$ & Place of creation \\
\hline 481 Chubb & US & Insurance & 21,097 & 1882 Chubb \& Son & New York NY \\
\hline 482 Teck Cominco & Canada & Manufacturing & 20,995 & $\begin{array}{l}1906 \text { Consolidated Mining and Smelting Company of } \\
\text { Canada }\end{array}$ & Kimberley, CA \\
\hline 483 Unibail-Rodamco & France & Banking and Finance & 20,959 & 1968 Unibail & Paris, FR \\
\hline 484 Orix & Japan & Banking and Finance & 20,922 & 1964 ORIX Corporation & Tokyo, JP \\
\hline 485 Copec & Chile & Oil, Gas and Mining & 20,921 & 1934 Compania de Petroleos de Chile & Santiago, CL \\
\hline 486 Nyse Euronext & US & Banking and Finance & 20,901 & 1792 New York Stock Exchange & New York NY \\
\hline 487 Banco Popular Espanol & Spain & Banking and Finance & 20,829 & 1926 Banco Popular & Madrid, ES \\
\hline 488 PKO Bank & Poland & Banking and Finance & 20,827 & 1919 Pocztowa Kasa Oszczędności & Warsaw, PL \\
\hline 489 Boston Scientific & US & Health and Life Sciences & 20,779 & 1979 Boston Scientific & Natick MA \\
\hline 490 General Motors & US & Manufacturing & 20,767 & 1908 General Motors & Flint MI \\
\hline 491 Regions Financial New & US & Banking and Finance & 20,752 & 1856 First National Bank & Huntsville AL \\
\hline 492 Covidien & US & Health and Life Sciences & 20,568 & 1903 Kendall International & Walpole MA \\
\hline 493 Sainsbury $(J)$ & UK & Consumer Products \& Serv. & 20,495 & 1869 Sainsbury Store & London, UK \\
\hline 494 SLM & US & Banking and Finance & 20,475 & 1972 Sallie Mae & Reston VA \\
\hline $495 \mathrm{Man}$ & Germany & Manufacturing & 20,460 & 1840 Maschinenfabrik Augsburg AG & Augsburg, DE \\
\hline 496 Williams Cos. & US & Energy Services and Utilities & 20,444 & 1908 Williams Brothers & Fort Smith AR \\
\hline 497 Norfolk Southern & US & Business Services & 20,432 & 1838 Norfolk and Western Railway & Roanoke VA \\
\hline 498 China Shenhua Energy & China & Oil, Gas and Mining & 20,430 & 1984 China Refined Coal Company & Beijing, CN \\
\hline 499 Precision Castparts & US & Manufacturing & 20,400 & 1953 Precision Castparts & Portland OR \\
\hline 500 DnB Nor & Norway & Banking and Finance & 20,390 & 1822 Christiania Sparebank & Oslo, NO \\
\hline
\end{tabular}

